\title{
Role of DFNB1 mutations in hereditary hearing loss among assortative mating hearing impaired families from South India
}

Pavithra Amritkumar ${ }^{1,2}$, Justin Margret Jeffrey ${ }^{1}$, Jayasankaran Chandru ${ }^{1}$, Paridhy Vanniya $S^{1}$, M. Kalaimathi ${ }^{1}$, Rajagopalan Ramakrishnan ${ }^{3}$, N. P. Karthikeyen ${ }^{4}$ and C. R. Srikumari Srisailapathy ${ }^{1 *}$

\begin{abstract}
Background: DFNB1, the first locus to have been associated with deafness, has two major genes GJB2 \& GJB6, whose mutations have played vital role in hearing impairment across many ethnicities in the world. In our present study we have focused on the role of these mutations in assortative mating hearing impaired families from south India.

Methods: One hundred and six assortatively mating hearing impaired (HI) families of south Indian origin comprising of two subsets: 60 deaf marrying deaf (DXD) families and 46 deaf marrying normal hearing (DXN) families were recruited for this study. In the 60 DXD families, 335 members comprising of $118 \mathrm{HI}$ mates, 63 other $\mathrm{HI}$ members and 154 normal hearing members and in the 46 DXN families, 281 members comprising of $46 \mathrm{HI}$ and their 43 normal hearing partners, 50 other $\mathrm{HI}$ members and 142 normal hearing family members, participated in the molecular study. One hundred and sixty five (165) healthy normal hearing volunteers were recruited as controls for this study. All the participating members were screened for variants in GJB2 and GJB6 genes and the outcome of gene mutations were compared in the subsequent generation in begetting deaf offspring.

Results: The DFNB1 allele frequencies for DXD mates and their offspring were 36.98 and 38.67\%, respectively and for the DXN mates and their offspring were 22.84 and $24.38 \%$, respectively. There was a $4.6 \%$ increase in the subsequent generation in the DXD families, while a $6.75 \%$ increase in the DXN families, which demonstrates the role of assortative mating along with consanguinity in the increase of DFNB1 mutations in consecutive generations. Four novel variants, p.E42D (in GJB2 gene), p.Q57R, p.E101Q, p.R104H (in GJB6 gene) were also identified in this study.

Conclusion: This is the first study from an Indian subcontinent reporting novel variants in the coding region of GJB6 gene. This is perhaps the first study in the world to test real-time, the hypothesis proposed by Nance et al. in 2000 (intense phenotypic assortative mating mechanism can double the frequency of the commonest forms of recessive deafness [DFNB1]) in assortative mating $\mathrm{HI}$ parental generation and their offspring.
\end{abstract}

Keywords: Assortative mating, GJB2 mutations, GJB6 mutations, DFNB1, Deafness, South India

\section{Background}

Hearing is one of the vital sensations, which keeps humans connected with each other and the world around. Consequently, hearing loss can have a profound impact on cognitive, psychosocial and educational development of an individual. Greater part of our present day

\footnotetext{
*Correspondence: crsrikumari@gmail.com; srikumaripavithra@gmail.com ${ }^{1}$ Department of Genetics, Dr. ALM Post Graduate Institute of Basic Medical Sciences, University of Madras, Taramani, Chennai 600113, India Full list of author information is available at the end of the article
}

knowledge on the physiology of hearing has come from various studies on hearing loss.

Till date, nearly 80 genes in over 142 deafness loci are associated with non-syndromic hearing loss (NSHL) reflecting the heterogenic and complex nature of the mechanism of hearing. Approximately 1200 different deafness-causing mutations are identified across the human genome. However, mutations do not occur at same frequencies across ethnicities. Eleven autosomal recessive loci (DFNB1, DFNB3, DFNB4, DFNB5, DFNB6, DFNB7/11, DFNB12, DFNB15, DFNB17, DFNB18 and

(c) The Author(s). 2018 Open Access This article is distributed under the terms of the Creative Commons Attribution 4.0 International License (http://creativecommons.org/licenses/by/4.0/), which permits unrestricted use, distribution, and reproduction in any medium, provided you give appropriate credit to the original author(s) and the source, provide a link to the Creative Commons license, and indicate if changes were made. The Creative Commons Public Domain Dedication waiver (http://creativecommons.org/publicdomain/zero/1.0/) applies to the data made available in this article, unless otherwise stated. 
DFNB95) and one autosomal dominant locus (DFNA59) are currently known to be associated with hearing loss in India (Hereditary hearing loss homepage, http://here ditaryhearingloss.org/). Despite this genetic heterogeneity across ethnicities, DFNB1 locus on chromosome 13q11-12, accounts for up to $50 \%$ of NSHL $[1,2]$. The first deafness associated gene in the DFNB1 locus, the GJB2 gene (GenBank M86849, MIM 121011) coding the gap junction protein, Connexin 26 (Cx26), was reported in 1997 [3]. Connexin 26 protein is found in the cochlea of the inner ear and is a major regulator of $\mathrm{K}^{+}$homeostasis. In the absence of $\mathrm{K}^{+}$circulation, the hair cells are unable to generate action potential in response to sound. Recent studies have suggested that they play an important role in inter and intracellular signaling pathways of the inner ear [4]. Over 220 mutations, polymorphisms and unknown variants in the GJB2 gene have been reported worldwide ([5]; Connexins and deafness homepage, http://davinci.crg.es/deafness/).High prevalence of GJB2 mutations among many populations has made it necessary to depend on molecular testing for diagnosis. However, nearly $10-50 \%$ of deaf subjects in many studies showing only one GJB2 mutant allele, further complicated the molecular diagnosis of DFNB1 deafness [6]. This led to the hypothesis that there could be other mutations in the DFNB1 locus but outside the GJB2 gene. Subsequently, two large deletions occurring in the GJB6 gene, which encodes connexin $30(\mathrm{Cx} 30)$ protein and lying $\sim 35 \mathrm{~kb}$ telomeric to GJB2 on chromosome 13, were reported [6, 7]. Cx30 protein is of size $30 \mathrm{kDa}$, having 261 amino acids and shares 77\% identity with Cx26. Cx26/Cx30 cochlear gap junctions forming heteromeric channels have been implicated in the maintenance of $\mathrm{K}+$ homeostasis in the inner ear and contributing to the inner ear homeostasis $[8,9]$. The GJB6 gene was first described as a causative in a rare dominant form of deafness, DFNA3, and its implication in NSHL were ascertained through the identification of two large deletions, del(GJB6-D13S1830) of size $309 \mathrm{~kb}$ and del(GJB6-D13S1854) of size $232 \mathrm{~kb}$, which truncate the GJB6 gene [6, 7]. Till date, only four point mutations and four deletions in the GJB6 gene or the region upstream have been reported (http://hereditar yhearingloss.org/). Studies on common mutations in assortative mating families have not been accomplished in the Indian subcontinent till date, except for our preliminary findings from this study [10-12].

In the hearing impaired $(\mathrm{HI})$ population, assortative mating refers to the preference of a $\mathrm{HI}$ individual to marry another HI individual (deaf marrying deaf, or DXD) or a HI individual opting for a normal hearing individual as a partner (deaf marrying normal hearing, or DXN), with hearing impairment forming the basis for selection or non-selection. Segregation analysis with respect to the distribution of deaf and hearing offspring in such mating scan provide estimation of the proportion of such marriages that can have only deaf children (non-complementary matings), only hearing children (complementary matings), and those capable of producing both deaf and hearing children. A non-complementary mating is when both the deaf mates are homozygous for recessive alleles at the same locus, and can therefore produce only deaf offspring, while a complementary mating could be when mates either have non-genetic deafness or a combination of non-genetic deafness and recessive deafness, or both the mates having different forms of recessive deafness [13-15].

There are very few reports available on the mutational dynamics of assortative mating among the HI. The available reports state that between nineteenth and twentieth centuries, the frequency of HI children in the US with one or two HI parents increased by $38 \%$ from 0.064 to 0.089 [15]. These reports have focused only on assortative mating $\mathrm{HI}$ families as consanguinity as a practice was absent in these regions. Consanguineous marriage is a tradition that is commonly practiced among many parts of the world especially in North and Sub-Saharan Africa, Latin American communities, West, Central and South Asia where there is $10-50 \%$ prevalence of consanguinity among their general population [16]. In India, especially Tamil Nadu, Andhra Pradesh, and Karnataka overwhelmingly prefer and practice consanguineous marriages across all major religious groups and ethnic entities. There have been studies on hereditary hearing loss from south India reporting parental consanguinity of deaf subjects screened ranging between 32.55 and 54.10\% [17-19] In Tamil Nadu, the studies on childhood hearing impaired have shown parental consanguinity ranging from 28 to $50 \%$ [20].

Consanguinity leads to an increase in identity by decent for all loci, indiscriminately. In contrast, once recessive genes are expressed phenotypically, assortative mating creates "gametic phase disequilibrium" [21], or the non-random association and gametic transmission of potentially very rare alleles at unlinked loci (genocopies) that have similar effects on the phenotype. Thus genetic heterogeneity and consanguinity add further complexity to the genetic studies on assortative mating deaf families. There are no genetic studies till date that have addressed the genetic and socio demographic dynamics simultaneously, on assortatively mating $\mathrm{HI}$ families from India.

Deaf marrying deaf is an increasing trend with sign language being the preferred mode of communication. Despite their preferential choice of a HI mate, the preferential desire for offspring's hearing status has largely been only normal hearing. The HI mates consider their deafness as a disability, which is a sharp deviation from 'Deaf culture' prevalent in the western HI population. 
With more than $50 \%$ of hearing loss having genetic predisposition, it is very important to systematically analyze the role of genetic mutations in such matings. Therefore, screening for common mutations associated with hearing loss among assortatively mating $\mathrm{HI}$ couples and their families in Indian population would be essential to understand the role of incidence of hearing impairment in the subsequent generation, which forms the basis for this study.

\section{Methods}

Recruitment of participants and clinical data collection

One hundred and six (106) assortatively mating hearing impaired families comprising of $\mathbf{6 0}$ deaf marrying deaf, or DXD families and 46 deaf marrying normal hearing, or DXN families, predominantly from south India, with no familial interconnectivity, were recruited for this study. All international standards for ethical research were met and the Institutional Human Ethical Committee of the University of Madras, Post Graduate Institute of Basic Medical Sciences, Chennai, India, approved the study (Ref Nos: PGIBMS/CO/Human Ethical/2010-11/1458, PGIBMS/CO/Human Ethical/ 2011-12/546, IHEC Approval No: UM/IHEC/11-2013-I). Assortatively mating hearing impaired (HI) families were primarily identified through adult deaf organizations and associations for the HI, Alumni and ParentTeacher associations of deaf schools in the four states (Andhra Pradesh, Karnataka, Kerala and Tamil Nadu) of south India. Some families were also referred by ENT surgeons, audiologists, gynecologists and neonatologists wherein the family members were seeking genetic counseling pertaining to the incidence of hearing loss in the family. Only those families in which the proband was prelingual $\mathrm{HI}$ and married to a partner who was either of normal hearing status (DXN) or was also prelingual HI (DXD), with at least two generations of family members available for the study, were included. Written informed consent was obtained from all participants in every family. Detailed family pedigrees were drawn. Information on demography, nativity, consanguinity, age at onset of hearing loss, detailed prenatal and perinatal history, use of ototoxic drugs (aminoglycosides), etc. was documented through a structured schedule. Attitudinal preferences of the HI mates as well as the hearing partner in each of the family towards choice of mate, parental choice, preference towards hearing status of their child/ children, mode of communication and genetic testing were also documented. Where both the mates were $\mathrm{HI}$, information was obtained from at least two speaking relatives well informed about the family. Pre-test genetic counseling was provided to each of these families with the help of a sign language expert in our team. The degree of hearing loss for the participating members was evaluated through pure tone audiometry by measuring the air and bone conduction thresholds.

A total of 621 members comprising of hearing impaired and normal hearing from these 106 assortative mating families were recruited for this study (Table 1).

\section{GJB2 and GJB6 mutation analysis}

Genomic DNA was extracted by standard PCI method [22]. The coding region of GJB2 gene (exon 2) was PCR-amplified using primer pair GJB2-EX2-1F (5' -TCT CCC TGT TCT GTC CTA GC-30) and GJB2-EX2-1R (50-GAC AGC ATG AGA GGG ATG AG-3') with annealing temperature of $62{ }^{\circ} \mathrm{C}$. Amplification of the non-coding first exon and the flanking donor splicing site was carried out using Advantage-GC Genomic PCR kit (Clontech, Mountain View, USA) and PCR primers EXON 1A (5'-TCC GTA ACT TTC CCA GTC TCC GAG GGA AGA GG-3') and EXON $1 \mathrm{M}$ (5' -CCC AAG GAC GTG TGT TGG TCC AGC CCC-3') with conditions previously described by Ramshanker et al. [17], for all the HI members. Coding exon (exon 6) of GJB6 gene was amplified by hot-start PCR using overlapping primer pairs: GJB6-1F (5' - AGA CTA GCA GGG CAG GGA GT- 3') and GJB6-1R (5' - AGG GGT CAA TCC CAC ATT TC -3') measuring $676 \mathrm{bp}$; GJB6-2F (5' -GAT AGA GGG GTC GCT GTG GT -3') and GJB6-2R (5'- GGC TAC AGA AGG AAC TTT CAG G -3') measuring 494 bp with annealing temperature of $63{ }^{\circ} \mathrm{C}$ for both.

The amplified products were purified using QIAquick ${ }^{\circ}$ PCR purification kit (Qiagen, Valencia, CA, USA). Bidirectional sequencing of the purified $\mathrm{PCR}$ products were carried out applying the same set of primers and $A B I$ Prism Big-Dye Terminator 3.1 cycle sequencing reaction kit on an ABI 3730 automated sequencer (Applied Biosystems, Foster City, USA). The chromatogram sequences obtained were compared with the reference sequences of GJB2 and GJB6 in National Center for

Table 1 Distribution of hearing impaired and normal hearing members in the assortative mating families

\begin{tabular}{llllll}
\hline Type of Mating & $\begin{array}{l}\text { No. of hearing } \\
\text { impaired mates }\end{array}$ & $\begin{array}{l}\text { No. of hearing } \\
\text { partners }\end{array}$ & $\begin{array}{l}\text { Other hearing impaired members in } \\
\text { the family }\end{array}$ & $\begin{array}{l}\text { Other hearing members in } \\
\text { the family }\end{array}$ & $\begin{array}{l}\text { Total } \\
\text { Deaf marrying deaf (DXD) }\end{array}$ \\
$\begin{array}{l}\text { Deaf marrying normal } \\
\text { hearing (DXN) }\end{array}$ & 46 & 0 & 63 & 154 & 142 \\
\begin{tabular}{l} 
TOTAL \\
\hline
\end{tabular} & 166 & 46 & 50 & 113 & 296 \\
\hline
\end{tabular}


Biotechnology Information (NCBI: http://www.ncbi.nlm. nih.gov/) to identify any nucleotide base-pair changes.

Additionally, the affected members were screened for the presence of two large deletions in the GJB6 gene, del (GJB6-D13S1830) and del (GJB6-D13S1854) by amplifying the regions containing the breakpoint fragments $[6,7]$.

\section{In silico analysis of novel variants}

The bioinformatics tools used in this study to analyze the novel variants observed in the GJB2 and GJB6 genes were (i) Sorting Intolerant From Tolerant (SIFT), a sequence homology-based tool that predicts the phenotypic effect of amino acid substitution in a protein by scoring the substitution as tolerant or intolerant on the basis of sequence homology and physical properties of amino acids [23] and (ii) PolyPhen (Polymorphism Phenotyping), a tool which predicts possible impact of an amino acid substitution on the structure and function of a human protein using straight forward physical and comparative considerations [24]. The amino acid sequences of the native and variant proteins were then individually analyzed for physicochemical characteristics by Expasy's online ProtParam tool available at http://web.expasy.org/ protparam/ [25], and the results were compared.

\section{Homology modeling}

The three dimensional structure of human GJB6 was modeled from its protein sequence using the automatic modelling mode SWISS MODEL repository (http:// swissmodel.expasy.org/). This resultant model was based on the template 2zw3 (GJB2), which shared $74.42 \%$ sequence identity with GJB6. It should be noted that the modeled residue range for GJB6 was from amino acid 2 to 216 for a single chain. The protein structures were then minimized energetically using Swiss-PdbViewer [26]. The energy of the minimized protein was recorded. The native model was then mutated at the specified amino acid position using the "mutate" option in Swiss-PdbViewer, energy-minimized and the layer was saved as a ".pdb" file. The native and mutated proteins were crosschecked for alterations using Ramachandran plot at RAMPAGE portal available at http://mordred. bioc.cam.ac.uk/ rapper/rampage.php [27].

\section{Control study}

One hundred and sixty five (165) healthy and normal hearing volunteers aged 19 to 66 years, belonging to different castes and states of south India were recruited as controls for this study and were screened for the most common variants in GJB2 and GJB6 genes. All the controls were subjected to audiological profiling to record their normal hearing status.

\section{Results}

In the present study, consanguinity was recorded at two levels, parental consanguinity of the hearing impaired partners and consanguinity among the assortative mating partners in the $106 \mathrm{HI}$ families. It was observed that consanguinity was conspicuously high among the normal hearing parents of the 120 DXD mates (45\%), compared to that observed in the DXD mating (3.33\%) (Table 2). Parental consanguinity of affected partners of 46 DXN mating was lower (32.61\%) than the consanguinity observed in the DXN mating (39.13\%) (Table 3). Additionally, the parental consanguinity of normal hearing mates in DXN mating (10.87\%) was comparable with the parental consanguinity of the control group $(11.51 \%)$, both reflecting the consanguinity trend in the general population.

In the first subgroup of 60 DXD families, 335 members comprising of $118 \mathrm{HI}$ mates, 63 other HI members and 154 normal hearing members participated in the molecular study. In the second subgroup of 46 DXN families, 281 members comprising of $46 \mathrm{HI}$ and their 43 normal hearing partners, 50 other HI members and 142 normal hearing family members, participated in the molecular study. Two HI mates in DXD families and three normal hearing partners in DXN families did not consent for blood sampling.

\section{Outcome of GJB2 mutation screening}

Twenty three GJB2 variants were observed; 11 pathogenic, one novel variant and 11 polymorphisms (Table 4). Out of the $118 \mathrm{HI}$ mates, $63.79 \%$ (37/58) of the deaf husbands and $66.67 \%(40 / 60)$ of the deaf wives had at least one nucleotide change in the GJB2 gene. Fifteen different mutations/ variants in the GJB2 gene were observed among the $118 \mathrm{HI}$ mates (Table 5). A novel mutation, p.E42D hitherto unreported was observed in this study (Fig. 1).

Two dominant mutations, p.R75Q [11] and p.R184Q [12] were recorded for the first time in the Indian population through our study. The variants, p.V37I, p.T55 T and p.R165W were represented only once in this cohort.

Among the $46 \mathrm{DXN}$ families, $46 \mathrm{HI}$ individuals and 43 normal hearing mates were included in the molecular

Table 2 Consanguinity in parents of DXD mating and in DXD mating

\begin{tabular}{|c|c|c|c|c|}
\hline \multirow{2}{*}{$\begin{array}{l}\text { Type of marriage } \\
\text { based on } \\
\text { consanguinity }\end{array}$} & \multicolumn{3}{|c|}{ PARENTAL CONSANGUINITY } & \multirow{2}{*}{$\begin{array}{l}\text { In DXD } \\
\text { mating }\end{array}$} \\
\hline & $\begin{array}{l}\text { In husbands' } \\
\text { parents (\%) }\end{array}$ & $\begin{array}{l}\text { In wives' } \\
\text { parents (\%) }\end{array}$ & $\begin{array}{l}\text { Combined } \\
(\%)\end{array}$ & \\
\hline Consanguineous & $24(40 \%)$ & $30(50 \%)$ & $54(45 \%)$ & $2(3.33 \%)$ \\
\hline $\begin{array}{l}\text { Non } \\
\text { Consanguineous }\end{array}$ & $36(60 \%)$ & $30(50 \%)$ & $66(55 \%)$ & $58(96.67 \%)$ \\
\hline TOTAL & 60 & 60 & 120 & 60 \\
\hline
\end{tabular}


Table 3 Consanguinity in parents of DXN mating and in DXN mating

\begin{tabular}{lllll}
\hline $\begin{array}{l}\text { Type of marriage } \\
\text { based on } \\
\text { consanguinity }\end{array}$ & PARENTAL CONSANGUINITY & & & In DXN \\
\cline { 2 - 5 } mating & In wives' parents (\%) & Combined (\%) & $30(32.61 \%)$ & $18(39.13 \%)$ \\
\hline Consanguineous & $17(36.96 \%)$ & $13(28.26 \%)$ & $62(67.39 \%)$ & $28(60.87 \%)$ \\
Non Consanguineous & $29(63.04 \%)$ & $33(71.74 \%)$ & 92 & 46 \\
TOTAL & 46 & 46 & 92 & \\
\hline
\end{tabular}

analysis. On GJB2 mutation screening, 56.52\% (26/46) of the HI partners and $41.86 \%(18 / 43)$ of the normal hearing partners had at least one nucleotide change in the GJB2 gene. The GJB2 mutations/variants observed among the affected and normal partners in DXN mating has been tabulated separately in Table 6. Ten different mutations/ variants in the GJB2 gene were observed among the participating mates of 46 DXN families. A rare variant p.T86M was observed for the first time in the Indian population. The mutations/ variants, p.W77X, p.A88A, p.V153I, p.R165W, p.M195I and p.P225P were represented only once in this cohort. The overall allelic frequency of GJB2 variants among the HI partners was $45.65 \%$, which was lower than the frequency observed in DXD mates. Interestingly, the allelic frequency of GJB2 variants in HI individuals with parental consanguinity (33.33\%) was much lower than those without parental consanguinity (59.09\%). The allelic frequency of GJB2 variants in the normal hearing partners was $22.09 \%$, is comparable with that observed in the normal hearing controls $(24.85 \%)$. The allelic frequency is higher in normal hearing mates with parental consanguinity (30\%) than those without parental consanguinity (21.05\%), similar to that observed in DXD mates.

The frequency of pathogenic GJB2 mutations was $33.90 \%$ in DXD mating (Table 5) and $35.86 \%$ in DXN mating (Table 6) with a combined frequency of $34.45 \%$. Among them, p.W24X was the most common mutation at a frequency of $25.42 \%$ in DXD mates and $30.43 \%$ in the affected members of DXN mating with a combined frequency of $27.93 \%$. More than $75 \%$ of the pathogenic alleles in this study had p.W24X mutation.

\section{Outcome of GJB6 mutation screening}

Hearing impaired individuals from both the types of mating, DXD and DXN, who were homozygous or compound heterozygous for pathogenic mutations in the coding and non-coding region of GJB2 gene were excluded for further screening. Thus, 33 HI DXD mates and 14 affected partners of DXN mating were excluded. One hundred and seventeen HI individuals comprising of 85 DXD mates and 32 affected DXN mates were included for further screening for mutations in the GJB6 gene. These included individuals with novel variants in the GJB2 gene, heterozygous carriers of pathogenic mutations in the GJB2 gene or negative for pathogenic
GJB2 mutations. In addition, 110 normal hearing controls were also included for the study of GJB6 gene mutations.

\section{Large deletions- 309 kb deletion (GJB6-D13S1830) \& 232 kb deletion (GJB6-D13S1854) in GJB6 gene}

All the $117 \mathrm{HI}$ individuals (85 DXD mates and $32 \mathrm{HI}$ mates of DXN mating) and 110 normal hearing controls were negative for both the deletions, D13S1830 and D13S1854 in the GJB6 gene, checked by multiplex PCR method [6, 7].

\section{Point mutations in GJB6 gene}

Table 7 lists the GJB6 variants observed in the 85 DXD mates and $32 \mathrm{HI}$ partners of DXN mating by direct sequencing of the coding exon 6 of GJB6 gene. Three novel variants, p.Q57R, p.E101Q and p.R104H were observed in heterozygous condition in 4 individuals. These three novel variants were found in heterozygous condition in three DXD mating individuals and one DXN affected member. These novel variants are reported for the first time ever in the HI population. Figure 1 shows the partial chromatograms of novel variants observed in GJB6 gene.

\section{Genotypes of GJB2 \& GJB6 mutations}

The various GJB2 genotypes observed among the affected partners of 60 DXD families are listed in Table 8. Two mutations, p.W24X and p.W77X, a novel variant p.E42D, and polymorphisms, p.R127H and p.V153I, were found in homozygous state. Homozygous p.W24X was the most common pathogenic genotype observed with an overall frequency of $22.03 \%$. Two HI individuals showed triallelic combinations, with one having a rare triallelic combination R184Q/Q124X/ IVS1 + 1G > A, involving a dominant mutation p.R184Q [12] and another having a combination of W24X/T55T/R127H. In one individual, the novel variant p.E42D was also found in combination with another novel variant, p.R104H in the second auditory gene analyzed, GJB6, showing digenic inheritance.

The various GJB2 \& GJB6 genotypes observed among the affected partners and the normal hearing partners of 46 DXN families have been listed in Table 9. Three mutations, p.W24X, p.Q124X and p.T86M, have been found in homozygous state. Homozygous p.W24X is the 


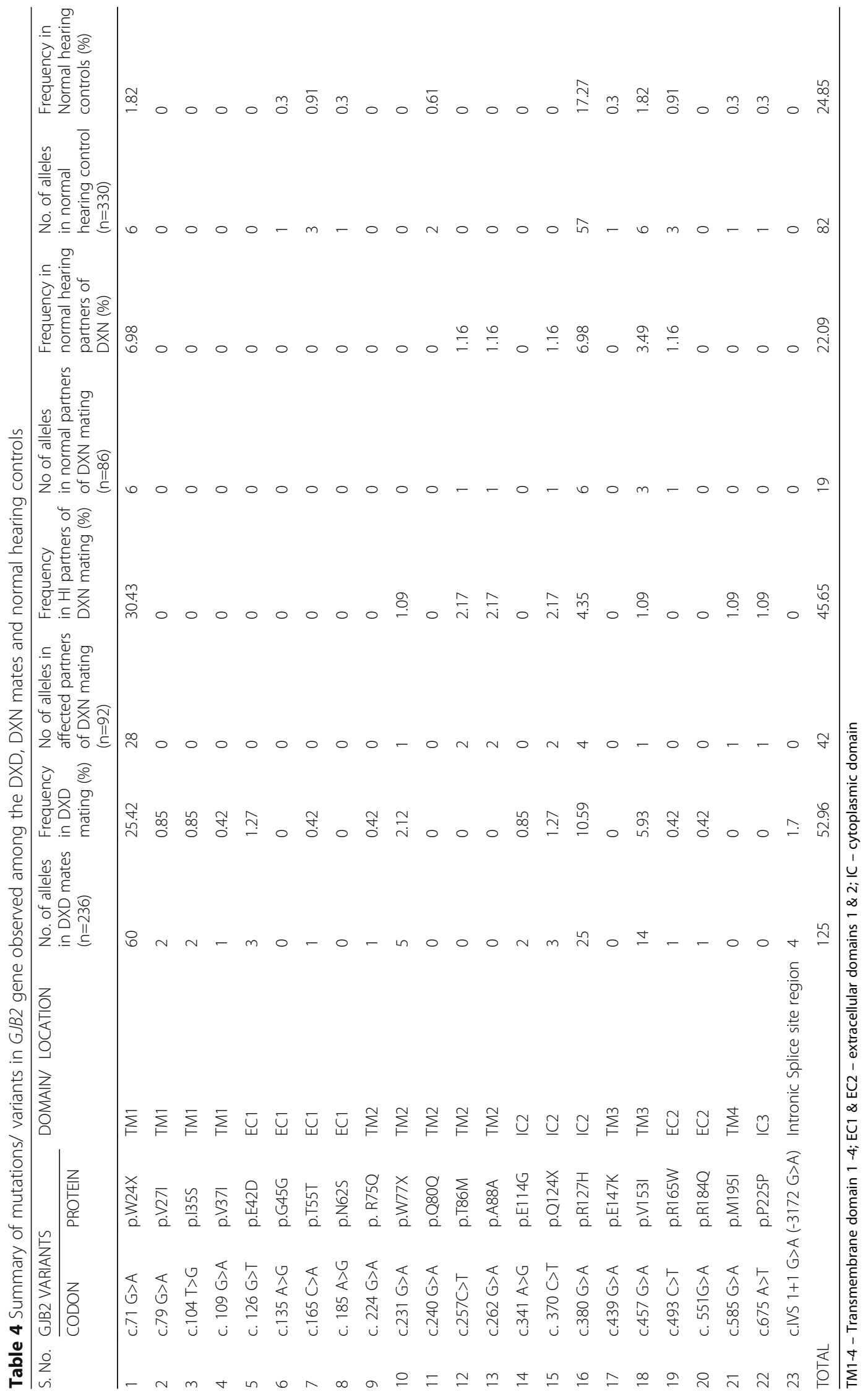


Table 5 Summary of pathogenic mutations/ variants in the GJB2 gene observed among the HI mates of 60 DXD families

\begin{tabular}{|c|c|c|c|c|c|c|c|c|c|c|c|c|}
\hline \multirow{2}{*}{$\begin{array}{c}S \\
\text { No }\end{array}$} & \multicolumn{2}{|c|}{ GJB2 VARIANTS } & \multirow{2}{*}{$\begin{array}{l}\text { DOMAIN/ } \\
\text { LOCATION }\end{array}$} & \multirow{2}{*}{ EFFECT } & \multirow{2}{*}{$\begin{array}{l}\text { No of alleles } \\
\text { in husbands } \\
\text { (116)* }\end{array}$} & \multirow{2}{*}{$\begin{array}{c}\text { Frequency } \\
\text { (\%) }\end{array}$} & \multirow{2}{*}{$\begin{array}{c}\text { No. of } \\
\text { alleles in } \\
\text { wives } \\
(120) \\
\end{array}$} & \multirow{2}{*}{$\begin{array}{c}\text { Frequency } \\
\text { (\%) }\end{array}$} & \multirow{2}{*}{$\begin{array}{c}\text { TOTAL } \\
\text { ALLELES } \\
(\mathrm{n}=236)\end{array}$} & \multirow{2}{*}{$\begin{array}{l}\text { OVERALL } \\
\text { FREQUENCY } \\
\text { (\%) }\end{array}$} & \multirow{2}{*}{$\begin{array}{l}\text { With parental } \\
\text { consanguinity } \\
(n=106)\end{array}$} & \multirow{2}{*}{$\begin{array}{c}\begin{array}{c}\text { Without } \\
\text { parental } \\
\text { consanguinity } \\
(\mathbf{n}=130)\end{array} \\
\end{array}$} \\
\hline & CODON & PROTEIN & & & & & & & & & & \\
\hline 1 & c.71 G>A & p.W24X & TM1 & $\begin{array}{c}\text { Nonsense mutation } \\
\text { (Transition); Pathogenic }\end{array}$ & 31 & 26.72 & 29 & 24.17 & 60 & 25.42 & 31 & 29 \\
\hline 2 & c. $79 \mathrm{G}>\mathrm{A}$ & p.V27I & TM1 & $\begin{array}{l}\text { Missense mutation } \\
\text { (Transition); Polymorphism }\end{array}$ & 1 & 0.86 & 1 & 0.83 & 2 & 0.85 & 1 & 1 \\
\hline 3 & c.104 $\mathrm{T}>\mathrm{G}$ & p.I35S & TM1 & $\begin{array}{c}\text { Missense mutation } \\
\text { (Transversion); Pathogenic }\end{array}$ & 0 & 0 & 2 & 1.67 & 2 & 0.85 & 1 & 1 \\
\hline 4 & c. $109 \mathrm{G}>\mathrm{A}$ & p.V37I & TM1 & $\begin{array}{c}\text { Missense mutation } \\
\text { (Transition); Pathogenic }\end{array}$ & 1 & 0.86 & 0 & 0 & 1 & 0.42 & 0 & 1 \\
\hline 5 & c. $126 \mathrm{G}>\mathrm{T}$ & p.E42D & EC1 & $\begin{array}{l}\text { Missense mutation } \\
\text { (Transversion);NOVEL }\end{array}$ & 1 & 0.86 & 2 & 1.67 & 3 & 1.27 & 3 & 0 \\
\hline 6 & c.165 C>A & p.T55T & EC1 & $\begin{array}{c}\text { Missense mutation } \\
\text { (Transversion); } \\
\text { Polymorphism } \\
\end{array}$ & 1 & 0.86 & 0 & 0 & 1 & 0.42 & 0 & 1 \\
\hline 7 & c. $224 \mathrm{G}>\mathrm{A}$ & p. R75Q⿱ & TM2 & $\begin{array}{c}\text { Missense mutation } \\
\text { (Transition); Pathogenic }\end{array}$ & 0 & 0 & 1 & 0.83 & 1 & 0.42 & 0 & 1 \\
\hline 8 & c. $231 \mathrm{G}>\mathrm{A}$ & p.W77X & TM2 & $\begin{array}{c}\text { Nonsense mutation } \\
\text { (Transition); Pathogenic }\end{array}$ & 2 & 1.72 & 3 & 2.5 & 5 & 2.12 & 2 & 3 \\
\hline 9 & c. $341 \mathrm{~A}>\mathrm{G}$ & p.E114G & IC2 & $\begin{array}{c}\text { Missense mutation } \\
\text { (Transition); Polymorphism }\end{array}$ & 1 & 0.86 & 1 & 0.83 & 2 & 0.85 & 1 & 1 \\
\hline 10 & c. $370 \mathrm{C}>\mathrm{T}$ & p.Q124X & IC2 & $\begin{array}{c}\text { Nonsense mutation } \\
\text { (Transition); Pathogenic } \\
\end{array}$ & 1 & 0.86 & 2 & 1.67 & 3 & 1.27 & 0 & 3 \\
\hline 11 & c. $380 \mathrm{G}>\mathrm{A}$ & p.R127H & IC2 & $\begin{array}{c}\text { Missense mutation } \\
\text { (Transition); Polymorphism }\end{array}$ & 13 & 11.21 & 12 & 10 & 25 & 10.59 & 13 & 12 \\
\hline 12 & c.457 G>A & p.V153I & TM3 & $\begin{array}{c}\text { Missense mutation } \\
\text { (Transition); Polymorphism }\end{array}$ & 6 & 5.17 & 8 & 5.83 & 14 & 5.93 & 5 & 9 \\
\hline 13 & c. $493 \mathrm{C}>\mathrm{T}$ & p.R165W & EC2 & $\begin{array}{c}\text { Missense mutation } \\
\text { (Transversion); } \\
\text { Polymorphism } \\
\end{array}$ & 0 & 0 & 1 & 0.83 & 1 & 0.42 & 1 & 0 \\
\hline 14 & c. $551 \mathrm{G}>\mathrm{A}$ & p.R184Q" & EC2 & $\begin{array}{c}\text { Missense mutation } \\
\text { (Transition); Pathogenic }\end{array}$ & 1 & 0.86 & 0 & 0 & 1 & 0.42 & 0 & 1 \\
\hline 15 & \multicolumn{2}{|c|}{$\begin{array}{l}\text { c.IVS } 1+1 \mathrm{G}>\mathrm{A} \\
(-3172 \mathrm{G}>\mathrm{A})\end{array}$} & EXON 1 & $\begin{array}{c}\text { Splice site mutation } \\
\text { (Transition); Pathogenic }\end{array}$ & 1 & 0.86 & 3 & 2.5 & 4 & 1.7 & 0 & 4 \\
\hline \multicolumn{5}{|c|}{ TOTAL } & 60 & 51.72 & 65 & 54.17 & 125 & 52.96 & $58(54.72 \%)$ & 67 (51.54\%) \\
\hline
\end{tabular}

most common pathogenic genotype observed in this sub group also with a frequency of $23.91 \%$, which is marginally higher than in DXD mating. The GJB2 genotypes observed among the control group have been listed out in Table 10 No GJB6 variants were observed among the normal hearing controls.

The overall carrier frequency for GJB2 pathogenic mutations, including the novel variants, among the $\mathrm{HI}$ mates, in both the sub groups included (DXD and affected partners of DXN mating), was $4.88 \%$, which was twice the frequency observed in the normal hearing controls $(2.42 \%)$. The carrier frequency of normal hearing partners of DXN mating was as high as $9.30 \%$.

\section{Novel variants in GJB2 and GJB6 genes}

Four novel variants, p.E42D (in GJB2 gene), p.Q57R, p.E101Q, p.R104H (in GJB6 gene) were identified in this study. This is the first study from Indian subcontinent reporting novel variants in the coding region of GJB6 gene.

p.E42D was observed at a frequency of $1.27 \%$ among the DXD mates. It is a missense mutation due to $G>T$ transversion at 126th nucleotide, resulting in a change from glutamic acid to aspartic acid at 42nd codon in the EC1 domain of the protein. It was observed in two DXD families, in homozygous, heterozygous as well as in compound heterozygous state along with a novel GJB6 mutation and variable phenotypes. In the first DXD family (DXD BND19, Fig. 2a) it was observed in homozygous state $(\mathrm{E} 42 \mathrm{D} / \mathrm{E} 42 \mathrm{D})$ in the female $\mathrm{DXD}$ mate \& in heterozygous state among her two siblings and her mother, all of whom showed variable phenotypes ranging from mild to profound, conductive, sensorineural and mixed type of hearing losses (Fig. 2b). The affected members did not have any other associated clinical features. The members with mild and moderate hearing losses were not aware of their hearing status until our audiometric evaluation.

In the second DXD family (DXD BLR47, Fig. 3a), the novel mutation was observed in compound heterozygous state $(\mathrm{E} 42 \mathrm{D} /+)$ along with a novel GJB6 gene mutation $(\mathrm{R} 104 \mathrm{H} /+)$ in the HI husband, suggesting a digenic interaction between the two. The affected elder sister showed a similar genotype involving the two novel variants in the GJB2 and GJB6 genes. The affected elder brother did not have any changes in the GJB2 gene and had only the novel variant in heterozygous condition $(\mathrm{R} 104 \mathrm{H} /+)$ in the GJB6 gene. Audiological evaluation of the affected husband, affected wife and affected elder brother showed them to have bilateral, profound, sensorineural hearing loss, while the affected elder sister had bilateral, moderately severe, sensorineural hearing loss (Fig. 3b). The affected elder brother had goiter, which appeared in the second decade of his life. The affected members did not have any other associated clinical features. p.R104H is a $\mathrm{G}>\mathrm{A}$ transition at 311th nucleotide resulting in a change from arginine to histidine at the 104th codon in the IC2 domain of the connexin 30 protein (Fig. 1). 
E42D/E42D Homozygous (c. $126 \mathrm{G}>\mathrm{T}$ ) NOVEL in $G J B 2$ gene

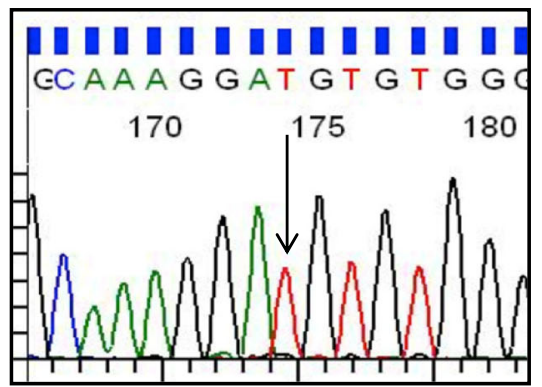

E42D/+ Heterozygous (c. $126 \mathrm{G}>$ T) NOVEL in $G J B 2$ gene

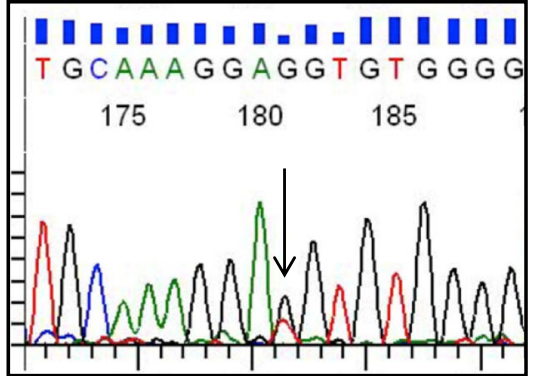

Q57R/+ Heterozygous (c.170 A>G) NOVEL in GJB6 gene

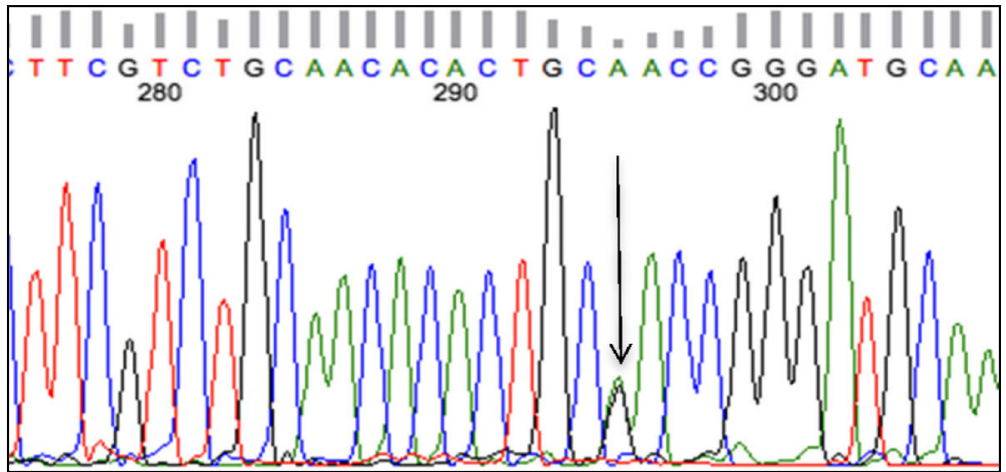

R104H/+ Heterozygous (c.311G $>$ A) NOVEL in $G J B 6$ gene

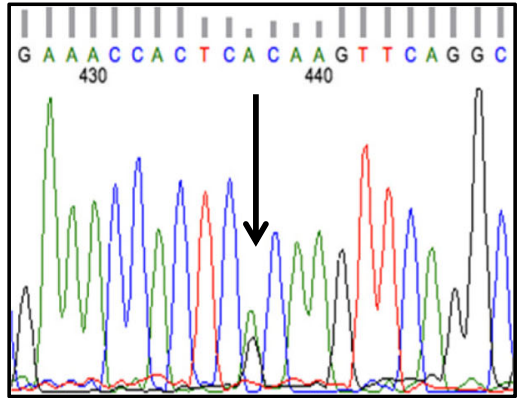

E101Q/+ Heterozygous (c.301G>C) NOVEL in GJB6 gene

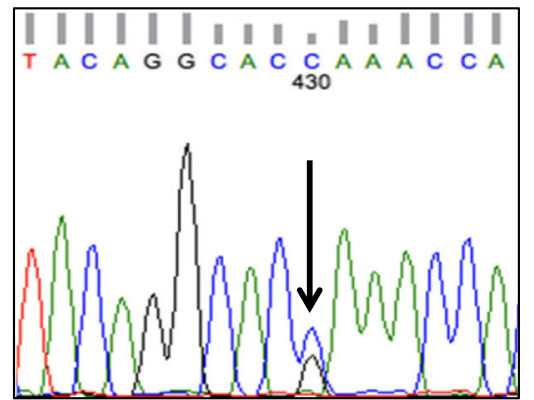

Fig. 1 Partial chromatograms of GJB2 and GJB6 variants observed in the study

The novel missense variant p.R104H in the GJB6 gene was observed at a frequency of $1.71 \%$ in the 117 $\mathrm{HI}$ individuals selected for the second level screening, in this study.

\section{p.Q57R variant (in GJB6 gene)}

p.Q57R, a novel missense variant, was observed in the GJB6 gene at a frequency of $0.85 \%$ in the $117 \mathrm{HI}$ individuals. This variant was observed in only one DXD mate in a heterozygous condition (Q57R/+) with no associated GJB2 gene mutations (Fig. 4). The DXD couple did not have any changes in the GJB2 gene. The affected husband, his affected brother and sister had a novel variant p.Q57R in heterozygous condition (Q57R/+) in the GJB6 gene. The affected wife did not have any changes in the GJB6 gene. This novel mutation was not observed in the selected DXN mates and the normal hearing controls. p.Q57R is an A > G transition at 170th nucleotide resulting in a change from glutamine to arginine at the 57th codon in the EC1 domain of the connexin 30 protein (Fig. 1).

\section{p.E101Q variant (in GJB6gene)}

p.E101Q is a $\mathrm{G}>\mathrm{C}$ transition at the 301st nucleotide resulting in a change from glutamic acid to glutamine at 
Table 6 Summary of pathogenic mutations/ variants in the GJB2 gene observed among the HI and Normal hearing partners of 46 DXN families

\begin{tabular}{|c|c|c|c|c|c|c|c|c|c|c|c|}
\hline \multirow[b]{2}{*}{$\begin{array}{l}\text { S. } \\
\text { No }\end{array}$} & \multicolumn{2}{|c|}{ GJB2 VARIANTS } & \multirow[b]{2}{*}{ EFFECT } & \multicolumn{4}{|c|}{ HI partners $(n=46)$} & \multicolumn{4}{|c|}{ Normal Hearing partners ( $n=43^{*}$ ) } \\
\hline & CODON & PROTEIN & & $\begin{array}{l}\text { ALLELES } \\
(\mathrm{n}=92)\end{array}$ & $\begin{array}{c}\text { FREQUENCY } \\
\text { (\%) }\end{array}$ & $\begin{array}{c}\text { With parental } \\
\text { consanguinity } \\
\quad(n=48)\end{array}$ & $\begin{array}{c}\begin{array}{c}\text { Without } \\
\text { parental } \\
\text { consanguinity } \\
(n=44)\end{array} \\
\end{array}$ & $\begin{array}{c}\text { ALLELES } \\
(\mathrm{n}=86)\end{array}$ & $\begin{array}{c}\text { FREQUENCY } \\
\text { (\%) }\end{array}$ & $\begin{array}{c}\text { With } \\
\text { parental } \\
\text { consanguini } \\
\text { ty }(\mathrm{n}=10) \\
\end{array}$ & $\begin{array}{c}\text { Without } \\
\text { parental } \\
\text { consanguini } \\
\text { ty }(\mathrm{n}=76) \\
\end{array}$ \\
\hline 1 & c. $71 \mathrm{G}>\mathrm{A}$ & p.W24X & $\begin{array}{c}\text { Nonsense mutation } \\
\text { (Transition); Pathogenic }\end{array}$ & 28 & 30.43 & 11 & 17 & 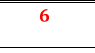 & 6.98 & 0 & 6 \\
\hline 2 & c. $231 \mathrm{G}>\mathrm{A}$ & p.W77X & $\begin{array}{c}\text { Nonsense mutation } \\
\text { (Transition); Pathogenic }\end{array}$ & 1 & 1.09 & $\mathbf{0}$ & 1 & $\mathbf{0}$ & $\mathbf{0}$ & $\mathbf{0}$ & $\mathbf{0}$ \\
\hline 3 & c. $257 \mathrm{C}>\mathrm{T}$ & p.T86M & $\begin{array}{c}\text { Missense mutation } \\
\text { (Transition); Pathogenic }\end{array}$ & 2 & 2.17 & 2 & 0 & 1 & 1.16 & 1 & 0 \\
\hline 4 & c. $262 \mathrm{G}>\mathrm{A}$ & p.A88A & $\begin{array}{c}\text { Missense mutation } \\
\text { (Transition); Polymorphism }\end{array}$ & 2 & 2.17 & 1 & 1 & 1 & 1.16 & 0 & 1 \\
\hline 5 & c. $370 \mathrm{C}>\mathrm{T}$ & p.Q124X & $\begin{array}{c}\text { Nonsense mutation } \\
\text { (Transition); Pathogenic }\end{array}$ & 2 & 2.17 & 0 & 2 & 1 & 1.16 & 0 & 1 \\
\hline 6 & c. $380 \mathrm{G}>\mathrm{A}$ & p.R127H & $\begin{array}{c}\text { Missense mutation } \\
\text { (Transition); Polymorphism }\end{array}$ & 4 & 4.35 & 1 & 3 & 6 & 6.98 & 2 & 4 \\
\hline 7 & c. $457 \mathrm{G}>\mathrm{A}$ & p.V153I & $\begin{array}{c}\text { Missense mutation } \\
\text { (Transition); Polymorphism }\end{array}$ & 1 & 1.09 & 1 & $\mathbf{0}$ & 3 & 3.49 & 0 & 3 \\
\hline 8 & c. $493 \mathrm{C}>\mathrm{T}$ & p.R165W & $\begin{array}{c}\text { Missense mutation } \\
\text { (Transversion); } \\
\text { Polymorphism }\end{array}$ & 0 & 0 & $\mathbf{0}$ & 0 & 1 & 1.16 & $\mathbf{0}$ & 1 \\
\hline 9 & c.585 G>A & p.M195I & $\begin{array}{c}\text { Missense mutation } \\
\text { (Transition); Polymorphism }\end{array}$ & 1 & 1.09 & 0 & 1 & 0 & 0 & $\mathbf{0}$ & 0 \\
\hline 10 & c. $675 \mathrm{~A}>\mathrm{T}$ & p.P225P & $\begin{array}{c}\text { Missense mutation } \\
\text { (Transversion); } \\
\text { Polymorphism } \\
\end{array}$ & 1 & 1.09 & $\mathbf{0}$ & 1 & 0 & 0 & $\mathbf{0}$ & 0 \\
\hline \multicolumn{4}{|c|}{ TOTAL } & 42 & 45.65 & $16(33.33 \%)$ & 26 (59.09\%) & 19 & 22.09 & $3(30 \%)$ & $16(21.05 \%)$ \\
\hline
\end{tabular}

the 101st codon in the IC2 cytoplasmic domain of the connexin 30 protein (Fig. 1). This novel missense variant in the GJB6 gene was observed at a frequency of $0.85 \%$ in $117 \mathrm{HI}$ individuals. It was observed in only one affected female partner of a DXN family in a heterozygous condition $(\mathrm{E} 101 \mathrm{Q} /+)$ with no associated GJB2 mutations (Fig. 5).There was no parental consanguinity in both the sides, but the wife's side had history of deafness with four siblings affected. The couple had two affected monozygotic twins, but one of them died due to unspecified illness. The couple also had a normal hearing daughter, who did not participate in the study. The DXN couple, two affected siblings of the proband and the surviving affected son participated in the study. Audiological evaluation of the four affected members showed them to have bilateral, profound, sensorineural hearing loss. The affected members did not have any other associated clinical features. The HI wife, her HI son and her two HI siblings did not have any changes in the GJB2 gene. They all had the novel variant p.E101Q in the GJB6 gene in heterozygous condition (E101Q/+).It was absent in the 85 DXD mating individuals and the normal hearing controls. The normal hearing husband of the deaf mate in this DXN family was a carrier of the common polymorphism p.R127H in the GJB2 gene in heterozygous condition $(\mathrm{R} 127 \mathrm{H} /+)$, which was also present in the affected son.

\section{In silico analysis of novel variants observed in GJB2 and GJB6 genes}

We predicted the functional significance of the novel variant p.E42D identified in GJB2 and the 3 novel variants, p.Q57R, p.E101Q and p.R104H, identified in GJB6 using two in silico tools namely SIFT and PolyPhen2. Predictions by the former tool is based on the alignment of orthologous and/or paralogous protein sequences while the latter considers evolutionary conservation, the physiochemical differences, and the proximity of the substitution to predicted functional domains and/or structural features. The outputs of both tools show that p.Q57R and p.R104H may affect or damage the structure and functioning of the Cx30 protein, but p.E101Q is tolerable or benign. Also, p.E42D in GJB2 was predicted to be tolerable or benign (Table 11).

To further gain insight on the effect of these mutations on the physicochemical parameters of Cx26 or Cx30 protein, we analysed their native and mutant

Table 7 Novel GJB6 variants observed in DXD and DXN families

\begin{tabular}{|c|c|c|c|c|c|c|c|}
\hline \multirow{2}{*}{$\begin{array}{l}\text { S. } \\
\text { No. }\end{array}$} & \multicolumn{2}{|c|}{ GJB6 Variants } & \multirow{2}{*}{$\begin{array}{l}\text { Domain/ } \\
\text { Location }\end{array}$} & \multirow[t]{2}{*}{ Effect } & \multirow{2}{*}{$\begin{array}{l}\text { Alleles in DXD } \\
(n=170)^{*}\end{array}$} & \multirow{2}{*}{$\begin{array}{l}\text { Alleles in DXN } \\
(n=64)^{*}\end{array}$} & \multirow{2}{*}{$\begin{array}{l}\text { Overall Allelic } \\
\text { Frequency (\%) }\end{array}$} \\
\hline & Codon & Protein & & & & & \\
\hline 1 & c.311 G>A & p.R104H & IC2 & Missense mutation; Transition; NOVEL; Possibly pathogenic & $2(1.18 \%)$ & 0 & $0.85 \%$ \\
\hline 2 & c.170 $A>G$ & p.Q57R & EC1 & Missense mutation; Transition; NOVEL; Possibly pathogenic & $1(0.59 \%)$ & 0 & $0.43 \%$ \\
\hline 3 & C.301 G>C & p.E101Q & IC2 & Missense mutation; Transversion; NOVEL; Possibly pathogenic & 0 & $1(1.56 \%)$ & $0.43 \%$ \\
\hline
\end{tabular}

* HI mates with novel variants in the GJB2 gene, heterozygous carriers of pathogenic mutations in the GJB2 gene or negative for pathogenic GJB2 mutations were included for GJB6 mutation screening 
Table 8 Frequency and distribution of GJB2 and GJB6 genotypes observed among the 118 hearing impaired mates of DXD mating

\begin{tabular}{|c|c|c|c|c|c|c|c|}
\hline S. No. & GJB2 and GJB6 genotypes & HI Husband $(\mathrm{n}=58)^{*}$ & Frequency $\%$ & HI Wife $(n=60)$ & Frequency \% & Total $(n=118)$ & Combined Frequency (\%) \\
\hline I & GJB2-Biallelic \& Triallelic & & & & & & \\
\hline 1 & W24X/W24X & 13 & 22.41 & 13 & 21.67 & 26 & 22.03 \\
\hline 2 & V153I/N153| & 1 & 1.72 & 2 & 3.33 & 3 & 2.54 \\
\hline 3 & W77X/W77X & 1 & 1.72 & 1 & 1.67 & 2 & 1.7 \\
\hline 4 & $\mathrm{R} 127 \mathrm{H} / \mathrm{R} 127 \mathrm{H}$ & 1 & 1.72 & 1 & 1.67 & 2 & 1.7 \\
\hline 5 & $\mathrm{R} 127 \mathrm{H} / \mathrm{N} 153 \mathrm{l}$ & 1 & 1.72 & 1 & 1.67 & 2 & 1.7 \\
\hline 6 & V27I/E114G & 1 & 1.72 & 1 & 1.67 & 2 & 1.7 \\
\hline 7 & $\mathrm{E} 42 \mathrm{D} / \mathrm{E} 42 \mathrm{D}$ & 0 & 0 & 1 & 1.67 & 1 & 0.85 \\
\hline 8 & W77X/Q124X & 0 & 0 & 1 & 1.67 & 1 & 0.85 \\
\hline 9 & W24X/135S & 0 & 0 & 1 & 1.67 & 1 & 0.85 \\
\hline 10 & Q124X/IVS1+1G>A & 0 & 0 & 1 & 1.67 & 1 & 0.85 \\
\hline 11 & R75Q"N153l & 0 & 0 & 1 & 1.67 & 1 & 0.85 \\
\hline 12 & V37I/N153I & 1 & 1.72 & 0 & 0 & 1 & 0.85 \\
\hline 13 & V153I/R165W & 0 & 0 & 1 & 1.67 & 1 & 0.85 \\
\hline 14 & 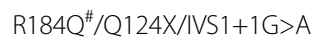 & 1 & 1.72 & 0 & 0 & 1 & 0.85 \\
\hline 15 & W24X/T55T/R127H & 1 & 1.72 & 0 & 0 & 1 & 0.85 \\
\hline$\|$ & GJB2-Monoallelic & & & & & & \\
\hline 1 & $\mathrm{R} 127 \mathrm{H} /+$ & 9 & 15.52 & 9 & 15 & 18 & 15.25 \\
\hline 2 & W24X/+ & 4 & 6.9 & 2 & 3.33 & 6 & 5.08 \\
\hline 3 & V1531/+ & 2 & 3.45 & 1 & 1.67 & 3 & 2.54 \\
\hline 4 & IVS1+1G>A/+ & 0 & & 2 & 1.67 & 2 & 1.7 \\
\hline 5 & |35S/+ & 0 & & 1 & 1.67 & 1 & 0.85 \\
\hline III & GJB6-Monoallelic & & & & & & \\
\hline 1 & $\mathrm{R} 104 \mathrm{H} /+$ & 1 & 1.72 & 0 & 0 & 1 & 0.85 \\
\hline 2 & Q57R/+ & 1 & 1.72 & 0 & 0 & 1 & 0.85 \\
\hline IV & GJB2/GJB6-Digenic & & & & & & \\
\hline 1 & $\mathrm{E} 42 \mathrm{D} /+; \mathrm{R} 104 \mathrm{H} /+$ & 1 & 1.72 & 0 & 0 & 1 & 0.85 \\
\hline
\end{tabular}

* Out of the 60 DXD couples comprising of 120 individuals, 2 individuals did not participate in the molecular study

${ }^{\#}$ Autosomal dominant mutations

structures individually in Expasy's ProtParam tool and compared the results (Table 12).

The native and the mutant proteins differ in their molecular weight and the number of atoms they are composed of. Moreover, the total number of positively charged residues increases from 29 to 30 in case of p.Q57R. On the other hand, p.R104H decreases the positively charged residues from 29 to 28 . The mutation p.E101Q reduces the number of negatively charged residues from 23 to 22 . The instability index of p.Q57R and p.R104H, shows a slight variation when compared to that of the native protein. p.Q57R tends to slightly increase the stability of the protein and in contrast p.R104H makes the protein more unstable. However, an instability value $>40$ suggests that the mutant forms as well as the native form are quite unstable since they are membrane channels. Moreover, a shift was observed in the GRAVY score for the mutants p.Q57R and p.R104H. Positive scores of GRAVY indicate the hydrophobic nature of the protein. p.Q57R reduces the hydrophobicity while p.R104H increases this property. There is no change in the aliphatic index and this high score (91.07) suggests that the native and the mutant proteins may retain their conformation over a wider range of temperatures.

The function of a protein not only relies on its properties but also on its three dimensional structure. Hence we queried RCSB Protein Data Bank for the 3-dimensional structures of $\mathrm{Cx} 26$ and $\mathrm{Cx} 30$ proteins. Only the crystal structure of $\mathrm{Cx} 26$ was available, which was downloaded and used for analyzing the effect of p.E42D mutation. The model was viewed with the help of Swiss-PdbViewer. The Glutamic acid at position 42 was found to be a part of an alpha helix and it was mutated to Aspartic acid in all 6 chains of the hexameric protein. Both the mutated and the native structures were subjected to Ramachandran Plot analysis through RAMPAGE 
Table 9 Frequency and distribution of GJB2 and GJB6 genotypes observed among the mates of DXN mating

\begin{tabular}{llllll}
\hline S. No. Genotypes & $\begin{array}{l}\text { Affected } \\
\text { Partner } \\
(\mathrm{n}=46)\end{array}$ & $\begin{array}{l}\text { Frequency } \\
(\%)\end{array}$ & $\begin{array}{l}\text { Normal } \\
\text { hearing } \\
\text { partner } \\
(\mathrm{n}=43)^{*}\end{array}$ & $\begin{array}{l}\text { Frequency } \\
(\%)\end{array}$ \\
\hline I & GJB2-Biallelic & & & \\
1 & W24X/W24X & 11 & 23.91 & 0 & 0 \\
2 & Q124X/Q124X & 1 & 2.17 & 0 & 0 \\
3 & T86M/T86M & 1 & 2.17 & 0 & 0 \\
4 & W24X/W77X & 1 & 2.17 & 0 & 0 \\
5 & W24X/A88A & 1 & 2.17 & 0 & 0 \\
6 & R153I/R165W & 0 & & 1 & 2.33 \\
6 & M195I/P225P & 1 & 2.17 & 0 & 0 \\
II & GJB2-Monoallelic & & & & \\
1 & W24X/+ & 4 & 8.7 & 6 & 13.95 \\
& T86M/+ & 0 & 0 & 1 & 2.33 \\
& Q124X/+ & 0 & 0 & 1 & 2.33 \\
2 & R127H/+ & 4 & 8.7 & 6 & 13.95 \\
3 & V153I/+ & 1 & 2.17 & 2 & 4.65 \\
4 & A88A/+ & 1 & 2.17 & 1 & 2.33 \\
III & GJB6-Monoallelic & & & & 0 \\
1 & E101Q/+ & 1 & 2.17 & 0 & 0 \\
\hline
\end{tabular}

* Out of the 46 normal hearing partners, three did not participate in the molecular study. All the three did not have any parental consanguinity

Table 10 Frequency and distribution of GJB2 genotypes observed among the 165 normal hearing controls

\begin{tabular}{llll}
\hline S.No. & GJB2 genotype & $\begin{array}{l}\text { Normal hearing control } \\
\text { population }(\mathrm{n}=165)\end{array}$ & Frequency \% \\
\hline 1 & W24X/+ & 5 & 3.02 \\
2 & N62S/+ & 1 & 0.61 \\
3 & E147K/T55T & 1 & 0.61 \\
4 & W24X/M195//P225P & 1 & 0.61 \\
1 & R127H/R127H & 5 & 3.02 \\
2 & R127H/R165W & 1 & 0.61 \\
3 & R127H/T55T & 1 & 0.61 \\
4 & V153I/R165W & 2 & 1.21 \\
5 & Q80Q/R127H & 1 & 0.61 \\
6 & R127H/+ & 44 & 26.67 \\
7 & V1531/+ & 4 & 2.41 \\
8 & Q80Q/+ & 1 & 0.61 \\
9 & T55T/+ & 1 & 0.61 \\
10 & G45G/+ & 1 & 0.61 \\
& & 69 & 41.82 \\
\hline
\end{tabular}

Online portal. The results showed that the mutation p.E42D did not alter the percentage of amino acid residues in the favorable, allowed and outlier regions of the plot (Fig. 6).

Connexin 30 structure was also modeled using SWISS MODEL repository. As expected, the QMEAN Z-score of the model was low $(-6.59)$, reinforcing the fact that it is a membrane protein. The predicted structure of Cx30 protein is shown in Fig. 7a and b with 7 Helices, 8 Strands and 13 Turns. In this model, Glutamic Acid (E) at position 101 and Arginine (R) at position 104 are part of alpha helices, while Glutamine (Q) at position 57 was found in the loop region that connects a beta sheet with alpha helix.

The mutant structures of Cx30 with the substituting amino acid at the above mentioned positions (p.Q57R, p.E101Q and p.R104H) were created with the help of Swiss-PdbViewer and saved as separate files. These structures were energy minimized and submitted to RAMPAGE online portal. Computation of Ramachandran plot showed that only p.Q57R is capable of changing the conformation of the protein, since the substitution decreased the number of residues in the favored region and increased the number of residues in the allowed region (Fig. 6).

\section{Genotype-phenotype correlation of GJB2/GJB6 mutations} in the incidence of hearing loss in DXD families

The 60 DXD families are further classified based on the genotype-phenotype correlation in the offspring with respect to the GJB2 and GJB6 mutations, as listed in Table 13. The table divides the 60 DXD mating families further into four groups: Group-I: Non-complementary mating families with all affected offspring only Group-II: Complementary mating families with all hearing offspring only Group-III: Segregating type families with both affected and normal hearing offspring Group-IV: Families with no offspring.

\section{Group I}

Seventeen families (28.33\%) belonged to this group where all offspring were affected. In 8 out of these 17 families, both the affected partners had GJB2 mutations in either homozygous condition or in compound heterozygous condition. In other words, $47.06 \%$ of the non-complementary matings were caused by GJB2 mutations. Overall, $13.33 \%$ of the DXD families were affected by GJB2 mutations. One among these 8 families had a unique triallelic pattern involving both a dominant mutation as well as recessive mutations of GJB2 gene (R184Q/ Q124X/ IVS1 + 1G > A), observed for the first time in the world [12].

In 3 other families, only one of the two deaf partners had either a homozygous, or heterozygous GJB2 mutation or a heterozygous GJB6 mutation, but had HI 


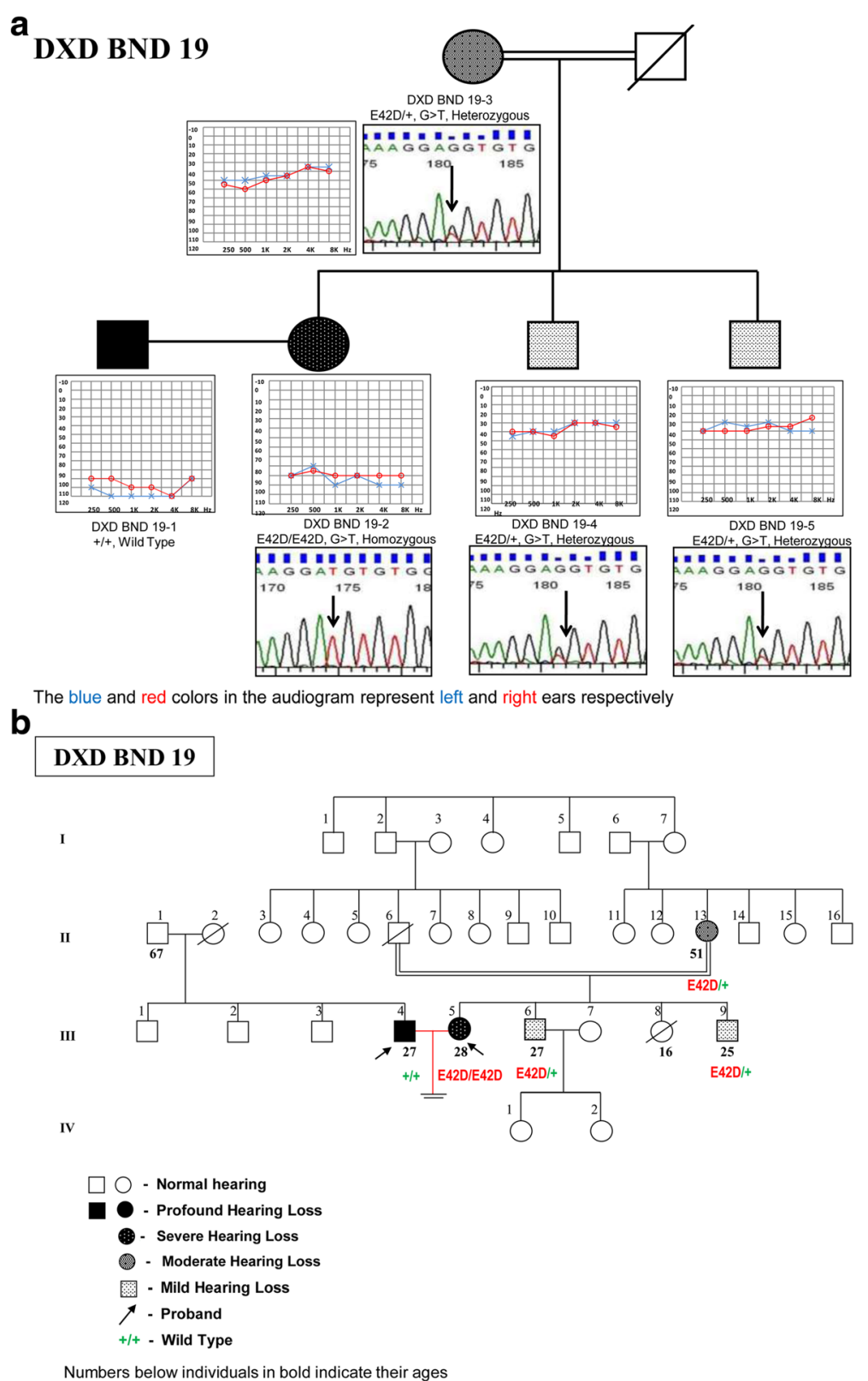

Fig. 2 a Genotype-Phenotype correlation in DXD BND 19 family with novel GJB2 mutation. b Pedigree of DXD BND 19 family showing novel mutation p.E42D in GJB2 gene

offspring. In the remaining 6 families, none of the partners had any GJB2/GJB6 mutations.

\section{Group II}

Thirty families (50\%) in this group had all normal hearing offspring. Eleven out of these families did not have any GJB2 or GJB6 mutations. In the remaining 19 families $(63.33 \%)$, one family had a combination of one deaf partner having GJB2 mutation in homozygous condition and other partner having a GJB2 mutation in heterozygous condition, but having normal hearing offspring. In the remaining 18 families, only one partner had a single GJB2 mutation in homozygous condition or heterozygous condition, or a GJB6 mutation in heterozygous condition.

\section{Group III}

Two families (3.33\%) out of the 60 DXD families had one normal hearing and one affected offspring each. One family was a non-GJB2 family with both the HI 
a

DXD BLR 47
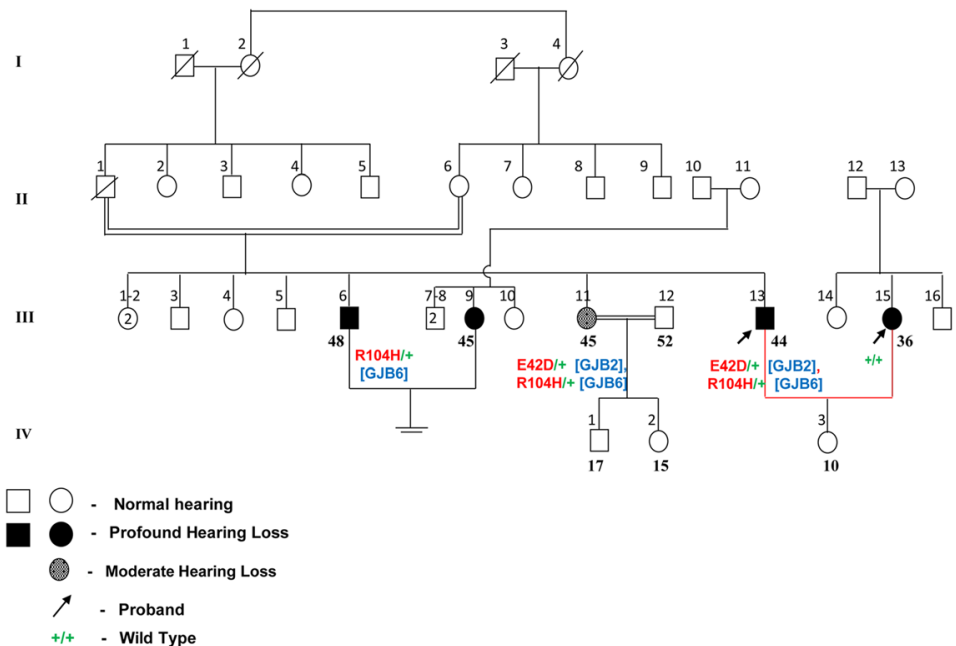

Numbers below individuals in bold indicate their ages

b

DXD BLR 47

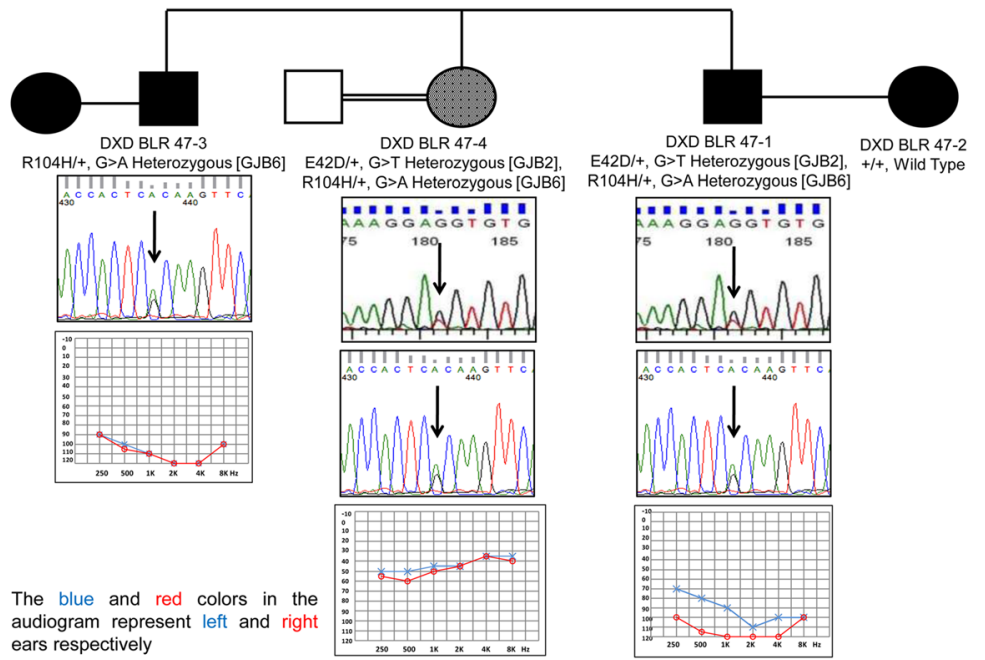

Fig. 3 a Pedigree of DXD BLR 47 family showing novel point mutations p.E42D\& p.R104H in GJB2\&GJB6 genes, respectively (digenic). b Genotype-Phenotype correlation in DXD BLR 47 family with novel GJB2/GJB6 mutations

partners not having any GJB2 mutations. In the second family in this group, one of the deaf partners had an autosomal dominant GJB2 mutation in heterozygous condition $(\mathrm{R} 75 \mathrm{Q} /+)$ with the affected offspring also inheriting the same from the parent [11].

\section{Group IV}

Eleven families (18.33\%) out of the 60 DXD families did not have any offspring. Five out of these families did not have any GJB2 or GJB6 mutations. In 1 out of the remaining 6 families, one deaf partner had homozygous GJB2 mutation while the other had in heterozygous condition. In the remaining 5 families, 4 families had one partner with a homozygous GJB2 mutation and the remaining one had one partner with novel GJB6 mutation in heterozygous condition (Q57R/+).

Role of GJB2/GJB6 mutations in the incidence of hearing loss in DXN families

The 46 DXN families were further classified based on consanguinity and the role of GJB2/ GJB6 mutations in the incidence of hearing loss, as the principle of complementarity cannot be applied to this subgroup at the phenotypic level. 

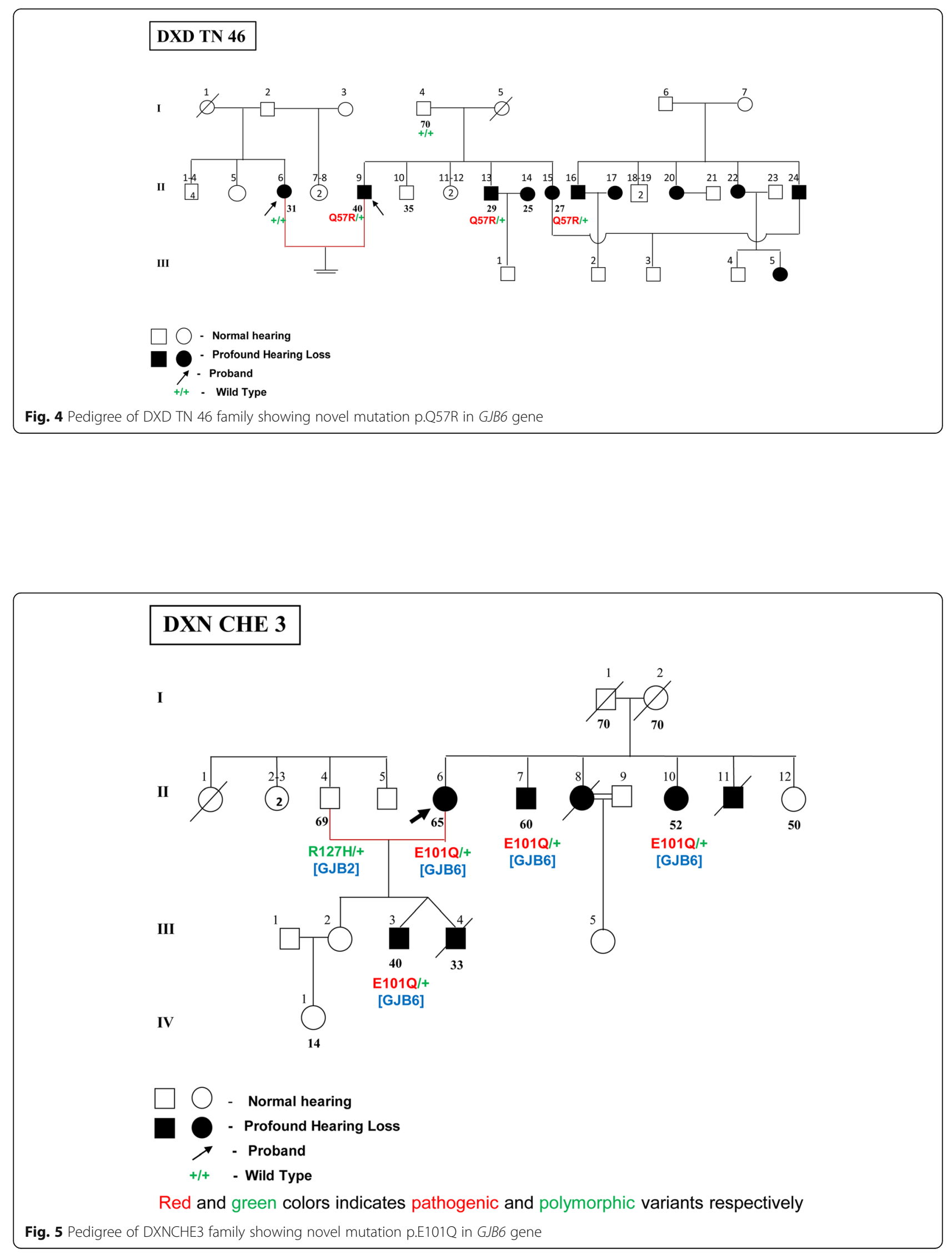
Table 11 Comparative analysis of the SIFT predictions for the novel variants in GJB2 and GJB6 genes

\begin{tabular}{|c|c|c|c|c|c|c|c|c|c|c|}
\hline \multirow[t]{3}{*}{ Mutation } & \multirow{2}{*}{\multicolumn{4}{|c|}{ SIFT }} & \multicolumn{6}{|c|}{ PolyPhen-2 } \\
\hline & & & & & \multicolumn{3}{|c|}{ HumDiv } & \multicolumn{3}{|c|}{ HumVar } \\
\hline & Score & $\begin{array}{l}\text { Median Sequence } \\
\text { conservation }\end{array}$ & $\begin{array}{l}\text { Sequences } \\
\text { represented } \\
\text { at position }\end{array}$ & Comment & Score & $\begin{array}{l}\text { Sensitivity, } \\
\text { Specificity }\end{array}$ & Comment & Score & $\begin{array}{l}\text { Sensitivity, } \\
\text { Specificity }\end{array}$ & Comment \\
\hline p.E42D (GJB2) & 0.57 & 3.05 & 42 & Tolerated & 0.038 & $0.94,0.82$ & Benign & 0.052 & $0.93,0.63$ & Benign \\
\hline p.Q57R (GJB6) & 0.00 & 3.09 & 35 & $\begin{array}{l}\text { Affect protein } \\
\text { function }\end{array}$ & 1.000 & $0.00,1.00$ & $\begin{array}{l}\text { Probably } \\
\text { damaging }\end{array}$ & 1.000 & $0.00,1.00$ & $\begin{array}{l}\text { Probably } \\
\text { damaging }\end{array}$ \\
\hline p.E101Q (GJB6) & 0.48 & 3.10 & 29 & Tolerated & 0.183 & $0.92,0.87$ & Benign & 0.114 & $0.90,0.69$ & Benign \\
\hline p.R104H (GJB6) & 0.01 & 3.09 & 35 & $\begin{array}{l}\text { Affect protein } \\
\text { function }\end{array}$ & 0.990 & $0.41,0.98$ & $\begin{array}{l}\text { Probably } \\
\text { damaging }\end{array}$ & 0.749 & $0.77,0.86$ & $\begin{array}{l}\text { Possibly } \\
\text { damaging }\end{array}$ \\
\hline
\end{tabular}

\section{Group-I families: Consanguineously mating DXN families with and without GJB2/GJB6 mutation affliction}

This group consisted of 18 DXN families (39.13\%), with consanguineous marriages. Twelve families (66.67\%) had affected offspring, indicating the role of consanguinity in the incidence of hearing loss. Eight families (44.44\%) had GJB2/GJB6 mutations in one or both the partners in homozygous or heterozygous conditions (Table 14). Five out of these 8 families had affected offspring, two had normal hearing offspring and in one family there was no offspring.

\section{Group II families: Non-consanguineously mating DXN} families with and without GJB2/GJB6 mutation affliction This group consisted of 28 DXN families (61.87\%), with non-consanguineous mating. Seven out of the 28 families $(25 \%)$ had affected offspring while $71.43 \%$ of these families had only normal hearing offspring (20/28). One family did not have offspring. Twelve out of the 28 families (42.86\%) had GJB2/GJB6 mutations in one or both the partners in homozygous or heterozygous conditions (Table 15). Out of these 12 families, two families
(16.67\%) had affected offspring, one of whom had a novel variant p.E101Q in the GJB6 gene in heterozygous condition, reported for the first time through this study. In 7 families, the affected partners have the most common mutation p.W24X in homozygous condition (W24X/W24X), five of whom have normal hearing offspring and one does not have any offspring.

\section{Statistical analysis for significance}

The GJB2 mutation frequency observed among the four study groups, (DXD mating, affected partners in DXN mating, normal hearing partners in DXN mating and the normal hearing controls) was compared using chi-square test, with the assumption that the differences if observed may be only due to chance. We observed that the chi-square value, which compares the differences between the observed and the expected values across the three groups, to be 58.21, with a $p$-value $<0.001$, which is highly significant (Table 16 ).

Table 12 Comparison of native and the mutant structure with p.E42D variant in Cx26 protein using Expasy's ProtParam tool

\begin{tabular}{|c|c|c|c|c|c|c|}
\hline \multirow[b]{2}{*}{ Property } & \multicolumn{2}{|l|}{ GJB2 } & \multicolumn{3}{|l|}{ GJB6 } & \multirow[b]{2}{*}{ p.R104H } \\
\hline & Native & p.E42D & Native & p.Q57R & p.E101Q & \\
\hline Number of amino acids & 226 & 226 & 261 & 261 & 261 & 261 \\
\hline Molecular weight & 26215 & 26201 & 30387.4 & 30415.5 & 30386.4 & 30368.4 \\
\hline Theoretical pl (Isoelectric point) & 9.11 & 9.11 & 8.81 & 8.92 & 8.92 & 8.68 \\
\hline Total number of negatively charged residues (Asp + Glu) & 18 & 18 & 23 & 23 & 22 & 23 \\
\hline Total number of positively charged residues (Arg + Lys) & 27 & 27 & 29 & 30 & 29 & 28 \\
\hline Total number of atoms & 3721 & 3718 & 4274 & 4280 & 4275 & 4268 \\
\hline Ext. coefficient assuming all pairs of Cys residues form cystines & 52410 & 52410 & 52410 & 52410 & 52410 & 52410 \\
\hline Ext. coefficient assuming all Cys residues are reduced & 51910 & 51910 & 51910 & 51910 & 51910 & 51910 \\
\hline Estimated half life (mammalian reticulocytes, in vitro) & 30 hrs & 30 hrs & 30 hrs & 30 hrs & 30 hrs & 30 hrs \\
\hline Instability index & 42.8 & 42.8 & 43.11 & 42.60 & 43.11 & 44.01 \\
\hline Aliphatic index & 98.67 & 98.67 & 91.07 & 91.07 & 91.07 & 91.07 \\
\hline Grand average of hydropathicity (GRAVY) & 0.288 & 0.288 & 0.055 & 0.051 & 0.055 & 0.06 \\
\hline
\end{tabular}




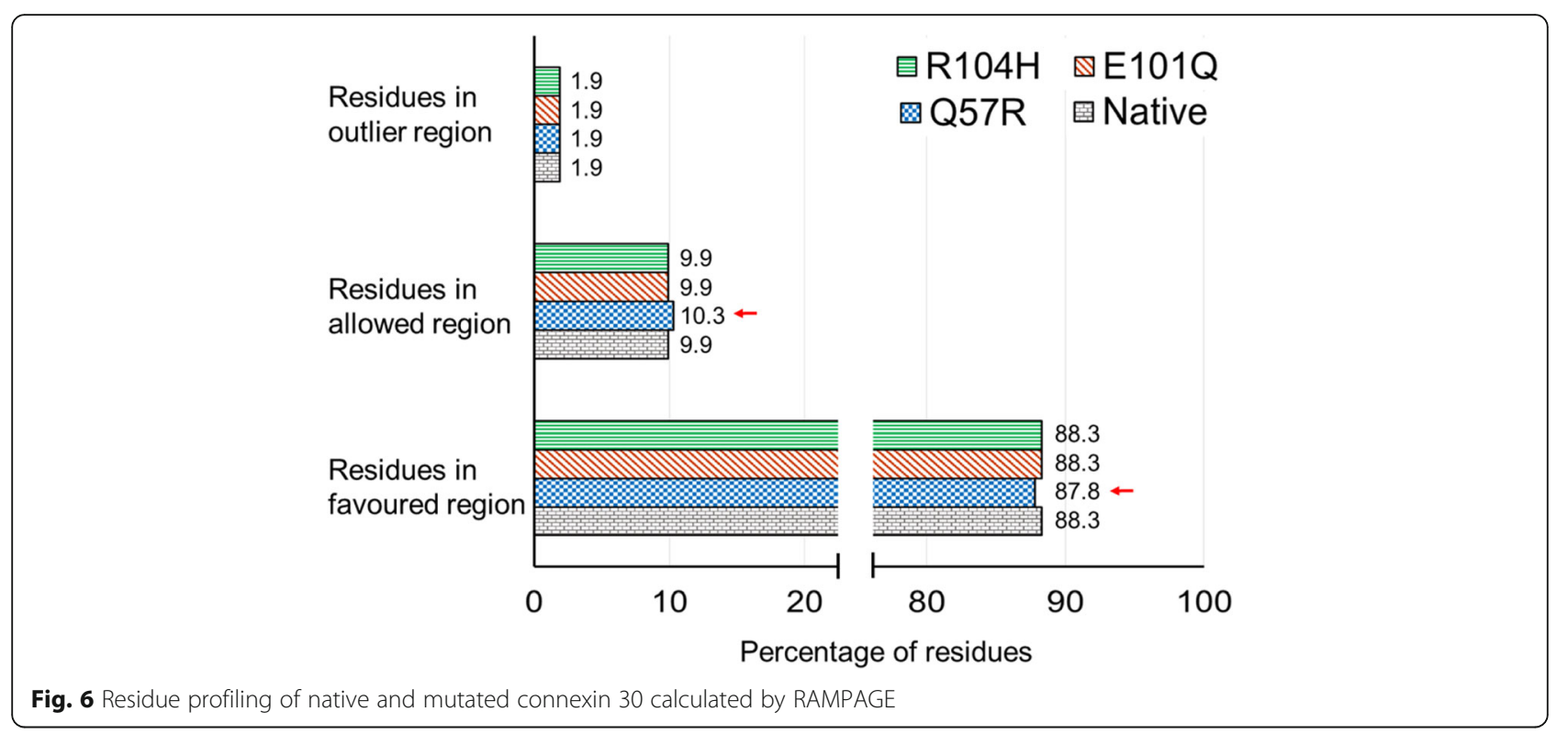

\section{Discussion}

Assortative mating as a form of non-random mating has the potential to act as an evolutionary agent. Assortative mating is capable of bringing together rare, non-allelic genes for the same phenotype, creating a non-random distribution of genes that has been termed "gametic-phase disequilibrium." It also increases the population variance. However, as the number of genes involved in creating a particular trait increases, assortative mating has a reduced capability to increase homozygosity at any one locus. There have been several studies on assortative mating among the deaf in the US. Edward Allen Fay [28], through his monumental work "Marriages among the Deaf in America", observed that marriages of the deaf had rapidly increased in America in that century, attributing largely to the establishment of schools for the deaf. Deaf marrying deaf constituted $72.5 \%$ of the married deaf population. Analysis of the DXD matings showed that $79 \%$ were "complementary" matings (i.e., only hearing offspring), $4.2 \%$ were "non-complementary" matings (capable of producing only deaf offspring), and the remaining $16.8 \%$ were "segregating" matings, in which the parents were capable of producing both deaf and hearing offspring.

This work was followed by another landmark work by Rose $[29,30]$ in which the data generated by Fay was compared with the contemporary data generated through a 1969 survey. Rose's results showed that between the 19th and 20th centuries, the frequency of deaf children with one or two deaf parents increased by $38 \%$. Among the deaf children through DXD mating, the estimated proportion of non-complementary marriages also increased by $23 \%$. Based on these observations and using computer simulations, Nance et al. proposed that the introduction of sign language 400 years ago in many Western countries and subsequent establishment of residential schools for the deaf could have favored assortative mating among deaf and relaxed genetic selection against deafness, leading to doubling of frequency of DFNB1 deafness in the United States in the last 200 years $[13,14]$. In a study on living deaf alumni of Gallaudet University, Arnos et al. [15] collected pedigree data on 311 marriages among deaf individuals. On the basis of segregation analysis on these 311 matings between deaf individuals, the authors reported that $23 \%$ were non-complementary, an increase of more than fivefold over the previous century's data of $4.2 \%$, as reported by Fay. Mutational analysis within these non-complementary mating individuals showed a statistically significant linear increase in the prevalence of pathologic GJB2 mutations. In addition to this, 199 probands with one or both parents deaf were also screened for GJB2 mutations and they too showed similar significant linear increase. In both these studies, c.35delG was the most common mutation in the GJB2 gene, ranging from 69 to $73 \%$. These data were consistent with the increase in the frequency of DFNB1 predicted by the previous simulation studies and provided convincing evidence over the influence of assortative mating on the frequency of common genes for deafness.

\section{DFNB1 dynamics in DXD families}

In our present study, we observed 17 families out of the 60 DXD families (28.33\%) to be non-complementary, i.e. with all affected offspring. This is higher than the Arnos et al.'s observation of $23 \%$. While Arnos' sampling was restricted to Gallaudet University alumni and not to a particular ethnicity or population, our study represents the south Indian HI population belonging to the four 

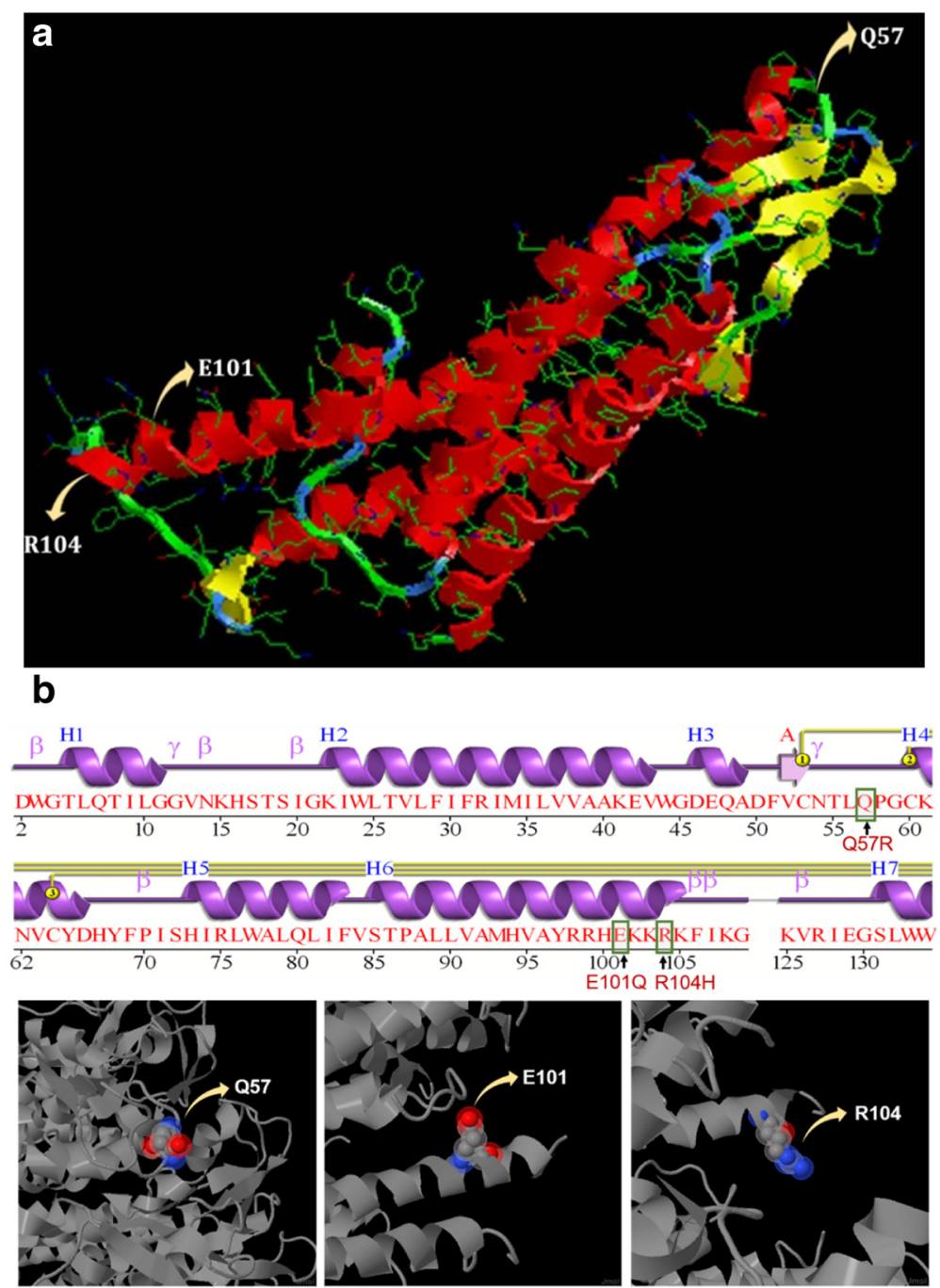

Fig. 7 a Predicted model of connexin 30 protein single chain indicating the positions of the variants, Q57, E101 \& R104 observed in this study. b: Wiring diagram and 3-D structure of connexin 30 protein showing the position of Q57, E101 and R104

southern states-Andhra Pradesh, Karnataka, Kerala and Tamil Nadu. In 8 families out of the 17 non-complementary mating families, both the affected partners had GJB2 mutations in either homozygous condition or in compound heterozygous condition (Table 8). Biallelic GJB2 mutations accounted for $13.33 \%$ of the DXD families and $47.06 \%$ of the non-complementary families.

In three other families from our 17, only one of the two deaf partners had either a homozygous, or heterozygous GJB2 mutation or a heterozygous GJB6 mutation, but with $\mathrm{HI}$ offspring. In two of these families, the affected offspring had one copy of the pathogenic DFNB1 allele indicating the possibility of probable role of these mutations in the incidence of hearing loss. This phenomenon has been explained by Arnos et al. [15] through their observation on GJB2 mutations among DXD families and their pedigree analysis. In their study, the pedigree analysis of such families suggested that many of the additional segregating matings reflect pseudo-dominant transmission in families when one parent with deafness resulting from GJB2 and/or GJB6 mutations married a partner who is deaf for reasons yet to be determined but was also a heterozygous carrier of a single GJB2 or GJB6 mutation. One of the important effect of assortative mating is the bringing together of rare, non-allelic genes (on different gene loci) for the same phenotype, creating a non-random distribution of genes that has been termed "gametic-phase disequilibrium." In our study the possibility of co-occurrence of non-allelic genes in the affected offspring in at least two families (Fig. 8a and b) may be due to gametic phase disequilibrium.

One of the most important observations from this study is out of these eight biallelic GJB2 mutation 


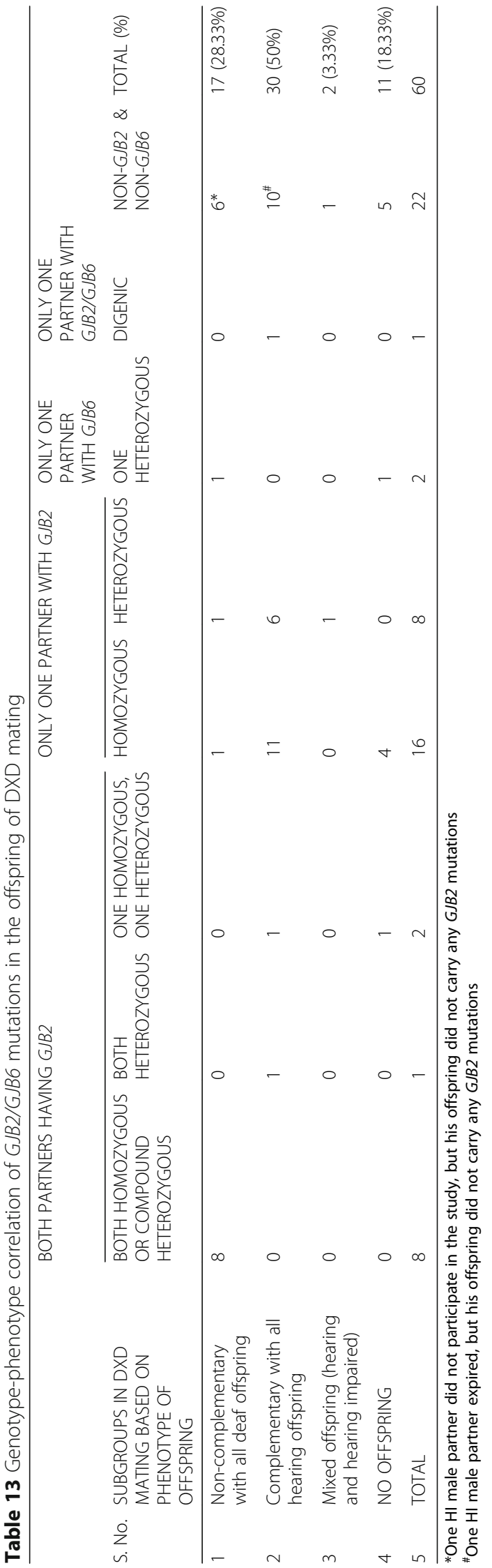


Table 14 Consanguineously mating DXN Families (Group I) with GJB2/GJB6 mutations

\begin{tabular}{|c|c|c|c|c|c|}
\hline $\begin{array}{c}\text { S } \\
\text { No. }\end{array}$ & Family ID & $\begin{array}{c}G J B 2 / G J B 6^{*} \\
\text { genotype in } \\
\text { Affected } \\
\text { Partner } \\
\end{array}$ & \begin{tabular}{|c|} 
GJB2/GJB6* \\
Genotype in \\
Normal hearing \\
partner
\end{tabular} & Offspring hearing status & Consanguinity type \\
\hline 1 & DXN NLR 9 & W24X/W77X & $\mathrm{W} 24 \mathrm{X} /+$ & $\begin{array}{c}\text { One affected and one } \\
\text { normal hearing }\end{array}$ & First Cousin type \\
\hline 2 & DXN TVC 18 & Q124X/Q124X & Q124X/+ & $\begin{array}{l}\text { One affected and one } \\
\text { normal hearing }\end{array}$ & First Cousin type \\
\hline 3 & DXN CHE 24 & T86M/T86M & $\mathrm{T} 86 \mathrm{M} /+$ & $\begin{array}{l}\text { One affected and one } \\
\text { normal hearing }\end{array}$ & Uncle-Niece type \\
\hline 4 & DXN CHE 32 & W24X/W24X & $\mathbf{W} 24 \mathrm{X} /+$ & $\begin{array}{l}\text { One affected and three } \\
\text { normal hearing }\end{array}$ & Uncle-Niece type \\
\hline 5 & DXN CHE 35 & W24X/W24X & W24X/+ & $\begin{array}{c}\text { One affected and one } \\
\text { normal hearing }\end{array}$ & Uncle-Niece type \\
\hline 6 & DXN NLR 8 & W24X/W24X & $+/+$ & Normal hearing & Uncle-Niece type \\
\hline 7 & DXN CHE 30 & W24X/W24X & W24X/R127H & Normal hearing & Distantly related \\
\hline 8 & DXN CHE 38 & W24X/A88A & A88A/+ & NO OFFSPRING & First Cousin type \\
\hline
\end{tabular}

*GJB6 mutations were absent in this group

The genotypes in column 3 refer to compound heterozygosity.

Red and Green colors indicate pathogenic and polymorphic variants respectively

carrying non-complementary mating DXD families, 50\% of them have p.W24X mutation in homozygous condition in both the partners. While one of these eight DXD pairs was related as first cousins, the remaining seven pairs were unrelated. This high prevalence of p.W24X mutations among the south Indian DXD families could be attributed to the high carrier rate (1.82\%) and high parental consanguinity (45\%) as observed in our study.

In our study, $50 \%$ of the 60 DXD families had only normal hearing offspring (complementary mating DXD families). In 19 of these DXD families, one of the mates had a GJB2/GJB6 mutation in homozygous or heterozygous condition. p.W24X mutation was the most common mutation, with 11 out of these 19 mates having it in homozygous condition and 7 of them having in heterozygous condition. In these 11 matings, the non-GJB2 partner possibly had mutations in genes that did not contribute towards an affected phenotype in the offspring in combination with the GJB2 mutation. The remaining 7 mates with heterozygous condition could simply be carriers of p.W24X mutation but with cause

Table 15 Non-consanguineously mating DXN families (Group II) with GJB2/GJB6 mutations

\begin{tabular}{|c|c|c|c|c|}
\hline S.No. & Family ID & $\begin{array}{c}\text { GJB2/GJB6 } \\
\text { genotype in } \\
\text { Affected } \\
\text { Partner }\end{array}$ & $\begin{array}{c}\text { GJB2/GJB6 } \\
\text { Genotype in } \\
\text { Normal hearing } \\
\text { partner }\end{array}$ & Offspring hearing status \\
\hline 1 & DXN MDY 43 & W24X/W24X & W24X/+ & Two affected \\
\hline 2 & DXN CHE 3 & $\begin{array}{l}\mathrm{E} 101 \mathrm{Q} /+ \\
(\text { GJB6) }\end{array}$ & R127H/+ & $\begin{array}{l}\text { Two affected and one } \\
\text { normal hearing }\end{array}$ \\
\hline 3 & DXN CHE 20 & W24X/W24X & $+/+$ & Normal hearing \\
\hline 4 & DXN CHE 21 & W24X/W24X & $+/+$ & Normal hearing \\
\hline 5 & DXN TVC 22 & W24X/W24X & $+/+$ & Normal hearing \\
\hline 6 & DXN CHE 36 & W24X/W24X & $+/+$ & Normal hearing \\
\hline 7 & DXN HSR 41 & W24X/W24X & V153I/+ & Normal hearing \\
\hline 8 & DXN NLR 7 & W24X/+ & $+/+$ & Normal hearing \\
\hline 9 & DXN NLR 10 & W24X/+ & $+/+$ & Normal hearing \\
\hline 10 & DXN TVC 28 & W24X/+ & $+/+$ & Normal hearing \\
\hline 11 & DXN HSR 40 & W24X/+ & $+/+$ & Normal hearing \\
\hline 12 & DXN CHE 48 & W24X/W24X & $+/+$ & NO Offspring \\
\hline
\end{tabular}

The genotypes in column 3 refer to compound heterozygosity.

Red and Green colors indicate pathogenic and polymorphic variants respectively. 
Table 16 Chi-square analysis of GJB2 variants among the four groups in our study

\begin{tabular}{|c|c|c|c|c|c|c|}
\hline S. No. & Group & & GJB2 Positive Alleles & GJB2 Negative Alleles & Total Alleles & Percentage (\%) \\
\hline \multirow[t]{2}{*}{1} & DXD-Both Affected Partners & Observed (O) & 125 & 111 & 236 & 52.96 \\
\hline & & Expected (E) & 85.01 & 150.99 & & \\
\hline \multirow[t]{2}{*}{2} & DXN- Affected Partners & Observed (O) & 42 & 50 & 92 & 45.65 \\
\hline & & Expected (E) & 33.14 & 58.86 & & \\
\hline \multirow[t]{2}{*}{3} & DXN-Normal Hearing Partners & Observed (O) & 19 & 67 & 86 & 22.09 \\
\hline & & Expected (E) & 30.98 & 55.02 & & \\
\hline \multirow[t]{4}{*}{4} & Control & Observed (O) & 82 & 248 & 330 & 24.85 \\
\hline & & Expected (E) & 124.88 & 205.12 & & \\
\hline & TOTAL & & 268 & 476 & 744 & \\
\hline & $\begin{array}{l}\text { Chi-Square Value } \\
\left(\Sigma(\mathrm{O}-\mathrm{E})^{2} / \mathrm{E}\right)\end{array}$ & & $58.21 \quad(P<0.001)$ & & & \\
\hline
\end{tabular}

for deafness lying in mutation or mutations in genes not associated with the DFNB1 locus. In the remaining one member, two novel GJB2 and GJB6 variants were observed in heterozygous condition showing digenic interaction, but his partner could be having a gene with no interaction with DFNB1 deafness causative factors.

In our study, 3.33\% of 60 DXD families were of segregating type with one affected and one normal hearing offspring. One of these families had a dominant GJB2 mutation, p.R75Q, in one partner and the affected offspring. This dominant mutation p.R75Q was observed for the first time in this study from India with non-syndromic presentation [11].

Interestingly, 11/60 DXD families (18.33\%) had no offspring and hence could not be classically categorized as complementary/ non-complementary mating. This group too demonstrated a high frequency of GJB2 mutations. In 6 of these families one of the mates carried GJB2/GJB6 mutations, both novel and known, in homozygous or heterozygous condition. In one particular childless DXD family, the husband was a p.W24X carrier while the wife was W24X homozygous. Further analysis of these 11 families for deafness associated infertility genes such as FOXI1, CATSPER2 and STRC could possibly throw more light on the etiology of this phenotype.

\section{DFNB1 dynamics in DXN families}

In our other study group of 46 DXN mating, we observed a higher rate of consanguinity $(39.13 \%)$ in their marriages compared to their parental consanguinity (32.61\%). Nearly $50 \%$ of the consanguineous DXN families had GJB2 mutations. Once again, p.W24X mutation was the most common mutation in this subgroup also, with one-third of the families having this mutation in homozygous or heterozygous condition. More than $60 \%$ of these consanguineous families have affected offspring and p.W24X mutation is implicated in $60 \%$ of them. The same factor has perhaps resulted in the surfacing of a rare pathogenic variant like p.T86 $\mathrm{M}$ (observed for the first time in India), persistently in two consecutive generations as a result of continuous inbreeding for three generations (Fig. 9). Our findings present consanguinity as an important and additional dimension to assortative mating contributing to hearing impairment in the Indian subcontinent. It also further reiterates that consanguinity factor along with genetic drift plays an important role in the survival and initial phenotypic expression of such rare GJB2 mutations.

Considering the non-consanguineous DXN mating families, only $7 \%$ were implicated with DFNB1 mutations. One-fourth of these families had affected offspring. Nearly $40 \%$ of the affected mates did have p.W24X mutation in homozygous or heterozygous condition. The presence of this mutation in this subgroup once again reiterates the high prevalence as well as high carrier rate of p.W24X mutation in south Indian population.

The overall allele frequency for DFNB1 mutations (GJB2 and GJB6 mutations) among the affected members in both the subgroups of assortatively mating was $35.67 \%$ while the carrier frequency for same among the affected members was $5.8 \%$. The carrier frequency in the normal hearing partners of the DXN subgroup was $9.30 \%$ while among the normal hearing control group was $2.42 \%$.

Role of novel variants in DFNB1 loci in assortative mating Four novel variants, p.E42D (in GJB2 gene), p.Q57R, p.E101Q, p.R104H (in GJB6 gene) were identified in this study. This is the first study from Indian subcontinent reporting novel variants in the coding region of GJB6 gene. In silico analysis of these variants using popular tools such as SIFT and PolyPhen2 revealed that p.Q57R and p.R104H may affect or damage the structure and functioning of $\mathrm{Cx} 30$ protein coded by GJB6, but p.E101Q in GJB6 and p.E42D in the GJB2 gene are tolerable or benign to the integrity of the protein structure. 
a

\section{DXD CHE 30}

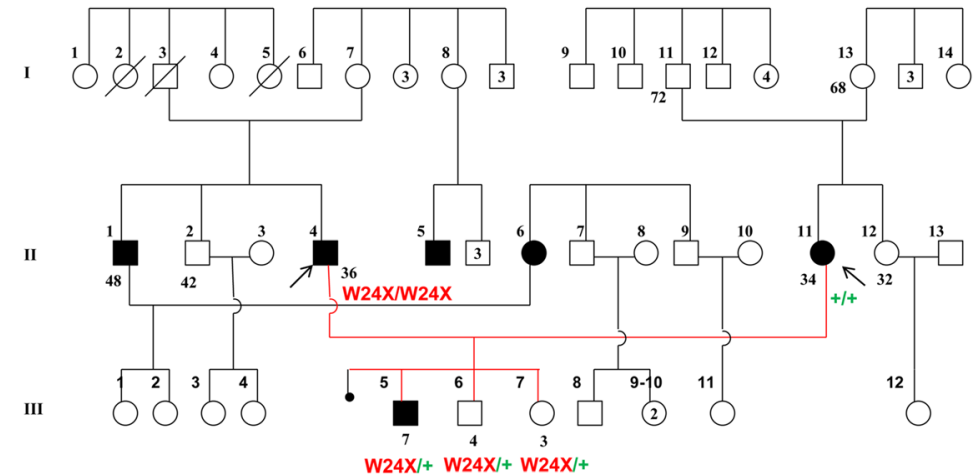

$\square \bigcirc$ - Normal hearing

- Profound Hearing Loss

- Proband

b

$+/+\quad$ - Wild Type

\section{DXD CHE 10}

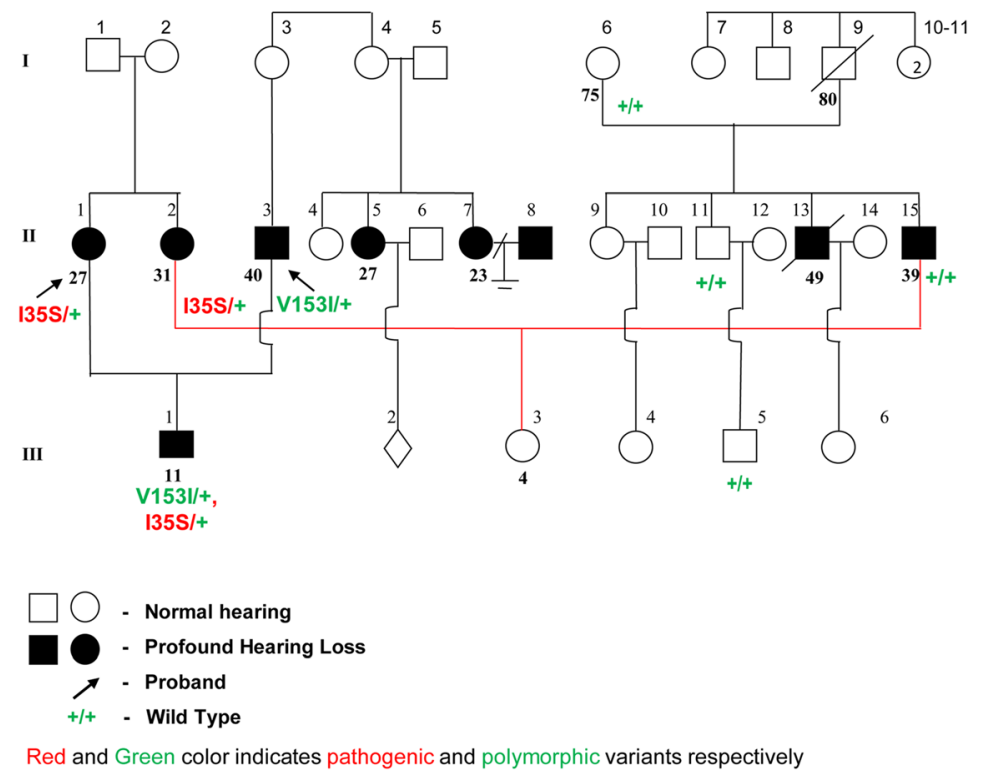

Fig. 8 a Pedigree of DXD CHE 30 family wherein there is possibility of nonallelic gene interaction leading to hearing impairment. $\mathbf{b}$ Pedigree of DXD CHE 10 family wherein there is possibility of non-allelic gene interaction leading to hearing impairment

However, p.E42D mutation was observed in both homozygous and heterozygous conditions in two unrelated $\mathrm{HI}$ individuals from different geographic and linguistic regions and with variable phenotypes in the family members ranging from mild to profound, conductive, sensorineural and mixed type of hearing losses. The individuals with other three GJB6 novel variants in heterozygous condition have also shown profound SNHL phenotype. These variants, perhaps contribute, in association with mutations in either unrelated or yet-to-be determined loci through unknown interactive pathways, for the observed phenotype. Further investigation of these samples through whole exome sequencing and functional analysis could perhaps throw more light into their mode of action.

We calculated the allele frequency of DFNB1 pathogenic mutations, including the novel variants, in two generations of our study group, the assortative mating partners forming one generation and their offspring forming the next generation. Only families in both the subgroups that had offspring were included. The DFNB1 allele frequencies for DXD mates and their offspring 


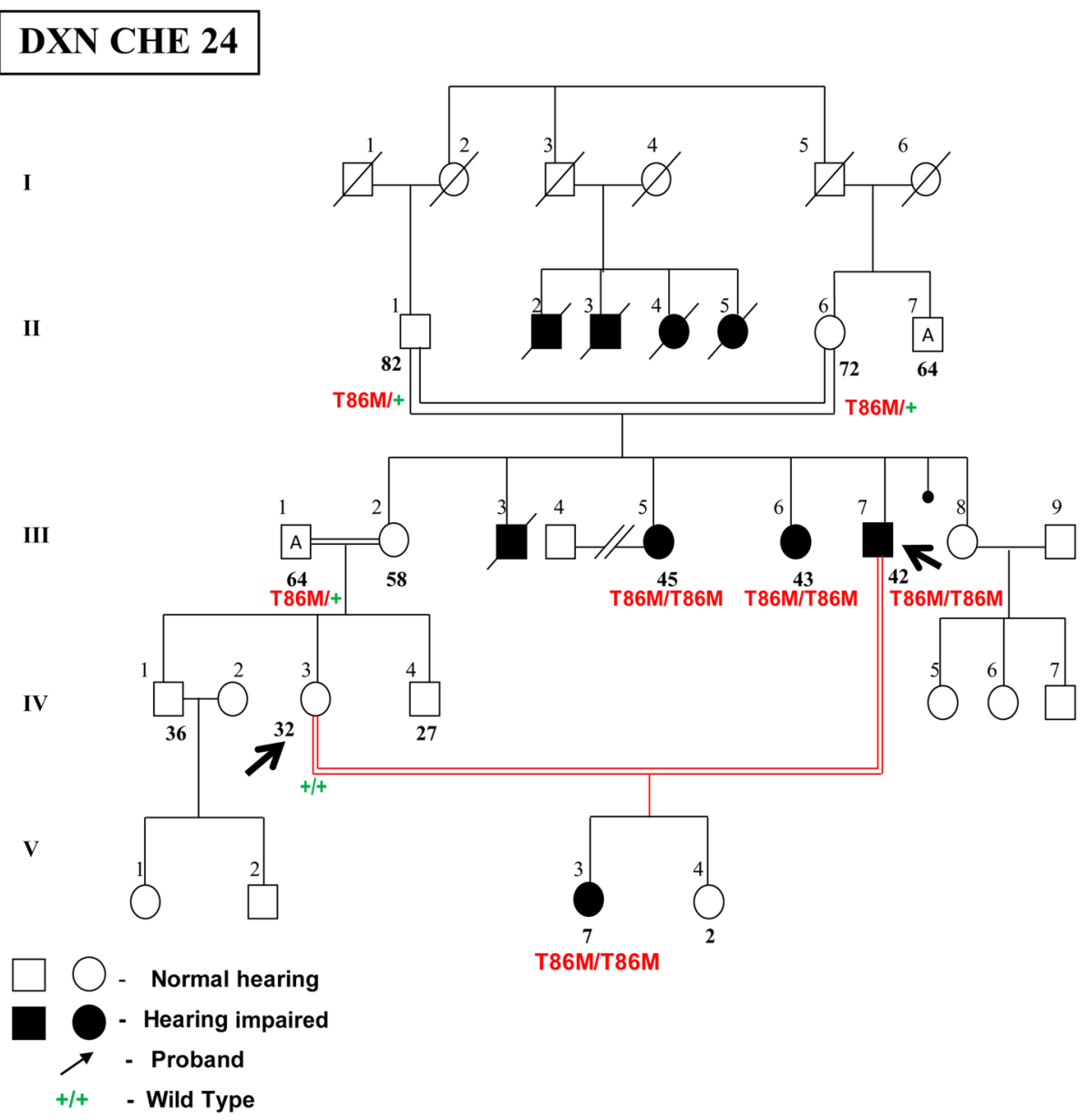

Fig. 9 Pedigree of DXN CHE 24 family showing p.T86 M, a rare GJB2 mutation in three consecutive generations owing to consanguinity

were 36.98 and $38.67 \%$, respectively and for the DXN mates and their offspring are 22.84 and $24.38 \%$, respectively. There was a $4.6 \%$ increase in the subsequent generation in the DXD families, while a $6.75 \%$ increase in the DXN families, which demonstrates the role of assortative mating along with consanguinity in the increase of DFNB1 mutations in consecutive generations. This is perhaps the first study in the world to test real-time, the hypothesis proposed by Nance et al. in 2000 (intense phenotypic assortative mating mechanism can double the frequency of the commonest forms of recessive deafness [DFNB1]) on assortative mating HI parental generation and their offspring.

Human populations are shaped not only by the usual forces of natural selection like famine, disease or climate but also through genetic variations. A new force is emerging with surprising implications wherein people themselves have started shaping their own evolution. This new force is the human culture, broadly defined as any learned behavior including technology. Assortative mating among the deaf is one such cultural force, which along with consanguinity can have a profound influence on genetic variations, which in turn can lead to an evolutionary change in times to come. From our study, several changing trends are already noticeable at various levels that include decline in family size, deviation from previously practiced endogamous caste limitations and attitudinal changes about hearing impairment as a disability. If the preference for a deaf to marry a deaf becomes a norm in future with the advent of rampant technological advancements that empower the deaf to be better educated and economically independent, the impact on the auditory gene pool/ phenotype has several outcomes like:

1. Increase in DFNB1 mutation frequencies from existing $\sim 35 \%$ as observed in our study to several folds, both in the deaf and in the normal population.

2. Deafness being a heterogeneous disorder, the remaining $\sim 65 \%$ of unresolved group of gene mutations (known and unknown) will also contribute further to the gene pool and alter this equation. 
3. As the genetic testing picks up gradually with cost-effective rapid multi-gene search in terms of whole genome, the knowledge may empower the prospective mates to choose partners of complementary type. This relaxed selection would again lead to simultaneous carrier status for a number of rare genes in normal hearing offspring of these mates. These normal hearing offspring may, in future, even develop variable levels of hearing losses as the proteins associated with mechanism of hearing tend to express variably.

4. Throwing newer combinations of unlinked multi-genic interactions and producing a deaf phenotype, confounding the research on the mechanism of hearing loss, there by complicating the path of unraveling the mystery of hearing.

\section{Conclusion}

This is the first study from an Indian subcontinent reporting novel variants p.Q57R, p.E101Q, p.R104H in the coding region of GJB6 gene. This is also the first study in the world to test real-time, the hypothesis proposed by Nance et al. in 2000 (intense phenotypic assortative mating mechanism can double the frequency of the commonest forms of recessive deafness [DFNB1]) in assortative mating $\mathrm{HI}$ parental generation and their offspring. The DFNB1 allele frequencies for DXD mates and their offspring were 36.98 and $38.67 \%$, respectively and for the DXN mates and their offspring are 22.84 and $24.38 \%$, respectively. There was a $4.6 \%$ increase in the subsequent generation in the DXD families, while a $6.75 \%$ increase in the DXN families, which demonstrated the role of assortative mating along with consanguinity in the increase of DFNB1 mutations in consecutive generations. This study has revealed that assortative mating among the deaf may well be a cultural force, which along with consanguinity can have a profound influence on genetic variations, which in turn can lead to an evolutionary change in times to come.

\section{Abbreviations}

Cx26: Connexin 26; Cx30: Connexin 30; DFNB: Deafness, autosomal recessive; DXD: Deaf marrying deaf; DXN: Deaf marrying normal hearing; EC1: Extracellular Ioop 1; GJB2: Gap Junction beta 2; GJB6: Gap Junction beta 6; HI: Hearing Impaired; IC2: Intracellular domain 2; NSHL: Non-syndromic hearing loss; PCR: Polymerase Chain Reaction; SNHL: Sensory neural hearing loss

\section{Acknowledgements}

We are grateful to the deaf families for their cooperation and participation in this study. We appreciate the support in Bioinformatic analysis provided by Dr. M. Manikandan, PGIBMS. We are thankful for the financial assistance provided through University Grants Commission (UGC) Major Grant (F.No.37-443/ 2009 (SR)) and Ad hoc Research Project (5/8/10-17(Oto)/CFP/2011-NCD-I) of the Indian Council of Medical Research (ICMR), Government of India, to CRS. AP was ICMR-SRF \& MK was ICMR-FA; JMJ was a UGC-UPE Phase II fellow and is currently CSIR-SRF; JC was supported by UGC-BSR; PVS was a JRF-TNPCB and is currently ICMR-SRF.

\section{Funding}

This study was funded by University Grants Commission (UGC) Major Grant (F.No.37-443/2009(SR)) and Ad hoc Research Project (5/8/10-17(Oto)/ CFP/2011-NCD-I) of the Indian Council of Medical Research (ICMR), Government of India, to CRS.

\section{Availability of data and materials}

The dataset and material analyzed in the present study is available from the corresponding author on request.

\section{Authors' contributions}

CRS, AP, JC, JMJ, RR and NPK contributed to the conceptualisation of this study and obtained funding. CRS, AP, JC, JMJ, SPV and MK recruited deaf families and controls for the study from four different states, collected detailed clinical data, family history and pedigrees, and isolated DNA from blood samples. AP and JMJ carried out all molecular analysis associated with DFNB1 mutations; RR \& NPK carried out the clinical investigations and audiometric profile for the subjects and controls; CRS \& AP prepared the original draft and all authors contributed to editing and review and provided intellectual input to the final manuscript. All authors read and approved the final manuscript.

\section{Ethics approval and consent to participate}

This research work involved the participation of humans in the form of deaf families and normal hearing volunteers. All procedures performed in this study were in accordance with the ethical standards of the institutional and/ or national research committee and with the 1964 Helsinki declaration and its later amendments or comparable ethical standards. Institutional Human Ethical Committee of the University of Madras, Post Graduate Institute of Basic Medical Sciences, Chennai, India, approved the study (Ref Nos: PGIBMS/ CO/Human Ethical/2010-11/1458, PGIBMS/CO/Human Ethical/2011-12/546, IHEC Approval No: UM/IHEC/11-2013-I). Informed consent was obtained from all individual participants included in the study.

\section{Consent for publication}

All subjects have approved the submission of the manuscript through written informed consent.

\section{Competing interests}

The authors declare that they have no competing interests.

\section{Publisher's Note}

Springer Nature remains neutral with regard to jurisdictional claims in published maps and institutional affiliations.

\section{Author details}

'Department of Genetics, Dr. ALM Post Graduate Institute of Basic Medical Sciences, University of Madras, Taramani, Chennai 600113, India. ${ }^{2}$ Current affiliation: PG and Research Department of Biotechnology, Women's Christian College, Chennai, India. ${ }^{3}$ Department of ENT, SRM Medical College Hospital and Research Centre, SRM Institute of Science and Technology, Kattankulathur, India. ${ }^{4}$ DOAST Hearing Care Center, Anna Nagar, Chennai 600040, India.

Received: 23 January 2018 Accepted: 18 May 2018

Published online: 19 June 2018

\section{Reference}

1. Kenneson A, Van Naarden Braun K, Boyle C. GJB2 (connexin 26) variants and nonsyndromic sensorineural hearing loss: a HuGE review. Genet Med. 2002;4: 258-74.

2. Snoeckx RL, Huygen PL, Feldmann D, Marlin S, Denoyelle F, Waligora J, et al. GJB2 mutations and degree of hearing loss: a multicenter study. Am J Hum Genet. 2005:77:945-57.

3. Kelsell DP, Dunlop J, Stevens HP, Lench NJ, Liang JN, Parry G, et al. Connexin 26 mutations in hereditary non-syndromic sensorineural deafness. Nature. 1997:387:80-3.

4. Dror AA, Avraham KB. Hearing loss: mechanisms revealed by genetics and cell biology. Annu Rev Genet. 2009:43:411-37.

5. Hilgert N, Smith RJH, Van Camp G. Forty-six genes causing nonsyndromic hearing impairment: which ones should be analyzed in DNA diagnostics? Mutat Res Rev Mutat Res. 2009;681(2):189-96. 
6. Del Castillo FJ, Rodríguez-Ballesteros M, Álvarez A, Hutchin T, Leonardi E, De Oliveira CA, et al. A novel deletion involving the connexin-30 gene, del(GJB6-d13s1854), found in trans with mutations in the GJB2 gene (connexin-26) in subjects with DFNB1 non-syndromic hearing impairment. J Med Genet. 2005;42:588-94.

7. del Castillo I, Villamar M, Moreno-Pelayo MA, del Castillo FJ, Álvarez A, Tellería $\mathrm{D}$, et al. A deletion involving the Connexin 30 gene in nonsyndromic hearing impairment. N Engl J Med. 2002;346:243-9.

8. Ahmad S, Chen S, Sun J, Lin X. Connexins 26 and 30 are co-assembled to form gap junctions in the cochlea of mice. Biochem Biophys Res Commun. 2003;307:362-8.

9. Marlin S, Feldmann D, Blons H, Loundon N, Rouillon I, Albert S, et al. GJB2 and GJB6 mutations: genotypic and phenotypic correlations in a large cohort of hearing-impaired patients. Arch Otolaryngol - Head Neck Surg. 2005:131:481-7.

10. Pavithra A, Jeffrey JM, Chandru J, Ramesh A, Srikumari Srisailapathy CR. High incidence of GJB2 gene mutations among assortatively mating hearing impaired families in Kerala: future implications. J Genet. 2014;93:207-13.

11. Pavithra A, Selvakumari M, Nityaa V, Sharanya N, Ramakrishnan R, Narasimhan $\mathrm{M}$, et al. Autosomal dominant hearing loss resulting from $\mathrm{p}$. R75Q mutation in the GJB2 gene: nonsyndromic presentation in a south Indian family. Ann Hum Genet. 2015;79:76-82.

12. Pavithra A, Chandru J, Jeffrey JM, Karthikeyen NP, Srisailapathy CRS. Rare compound heterozygosity involving dominant and recessive mutations of GJB2 gene in an assortative mating hearing impaired Indian family. Eur Arch Oto-Rhino-Laryngology. 2017;274:119-25.

13. Nance WE, Kearsey MJ. Relevance of Connexin deafness (DFNB1) to human evolution. Am J Hum Genet. 2004;74:1081-7.

14. Nance $W E$, Liu XZ, Pandya A. Relation between choice of partner and high frequency of connexin-26 deafness. Lancet. 2000;356:500-1.

15. Arnos KS, Welch KO, Tekin M, Norris WW, Blanton SH, Pandya A, et al. A comparative analysis of the genetic epidemiology of deafness in the United States in two sets of pedigrees collected more than a century apart. Am J Hum Genet. 2008:83:200-7.

16. Consanguinity BA. Its relevance to clinical genetics. Clin Genet. 2001;60:89-98.

17. RamShankar M, Girirajan S, Dagan O, Shankar HR, Jalvi R, Rangasayee R, Avraham KBAA. Contribution of connexin26 (GJB2) mutations and founder effect to non-syndromic hearing loss in India. J Med Genet. 2003;40:e68.

18. Padma G, Ramchander PV, Nandur UV, Padma T. GJB2 and GJB6 gene mutations found in Indian probands with congenital hearing impairment. J Genet. 2010;88:267-72.

19. Godbole K, Hemavathi J, Vaid N, Pandit AN, Sandeep MN, Chandak GR. Low prevalence of GJB2 mutations in non-syndromic hearing loss in western India. Indian J Otolaryngol Head Neck Surg. 2010;62:60-3.

20. Subathra M, Ramesh A, Selvakumari M, Karthikeyen NP, Srisailapathy CRS Genetic epidemiology of mitochondrial pathogenic variants causing nonsyndromic hearing loss in a large cohort of south Indian hearing impaired individuals. Ann Hum Genet. 2016;80:257-73.

21. Denniston $C$. Equivalence by descent: pedigree analysis with inbreeding and gametic phase disequilibrium. Ann Hum Genet. 2000;64:61-82.

22. Sambrook J, Fritsch EF, Maniatis T. Molecular cloning: a laboratory manual. Cold Spring Harb Lab Press. 1989;1:626.

23. Ng PC, Henikoff SSIFT. Predicting amino acid changes that affect protein function. Nucleic Acids Res. 2003;31:3812-4.

24. Ramensky V. Human non-synonymous SNPs: server and survey. Nucleic Acids Res. 2002;30:3894-900

25. Gasteiger E, Hoogland C, Gattiker A, Duvaud S, Wilkins MR, Appel RD, et al. Protein identification and analysis tools on the ExPASy server. In: Walker JM, editor. The Proteomics Protocols Handbook. Humana Press; 2005. p. 571-607.

26. Guex N, SWISS-MODEL PMC. The Swiss-PdbViewer: an environment for comparative protein modeling. Electrophoresis. 1997;18:2714-23.

27. Lovell SC, Davis IW, Arendall WB, de Bakker PIW, Word JM, Prisant MG, et al. Structure validation by Calpha geometry: phi,psi and Cbeta deviation. Proteins. 2003;50:437-50

28. Fay E. Marriages of the deaf in America. Washington, DC: Volta Bureau; 1898.

29. Rose S. Genetic studies of profound prelingual deafness (PhD dissertation). Bloomington: Indiana University; 1975.

30. Rose SP, Conneally PM, NW. Genetic analysis of childhood deafness. Child Deaf New York Grune Strat. 1977:19-35.

\section{Ready to submit your research? Choose BMC and benefit from:}

- fast, convenient online submission

- thorough peer review by experienced researchers in your field

- rapid publication on acceptance

- support for research data, including large and complex data types

- gold Open Access which fosters wider collaboration and increased citations

- maximum visibility for your research: over $100 \mathrm{M}$ website views per year

At BMC, research is always in progress.

Learn more biomedcentral.com/submissions 